\title{
Application of Multiple Regressions in Development of an Employee Turnover Model
}

\section{Ravichandan $\mathrm{K}^{*}$}

School of Business Studies, Madurai Kamaraj University, Madurai, India

\begin{abstract}
The life of the organizations has become more complex. Organizations had an enjoyable past but their future is not predictable. Believing in the past successes will not only lead to 'unsuccessful organizations', but also would be a case to learn 'how not to manage an organization'. Today every organization, to be effective is required to be more concerned with the questions of 'competitiveness' and 'continued existence'. A highly skilled workforce is the aorta of any organization. It is this work force that creates a sustainable competitive advantage to the organization Innovation takes hold. New products and services are conceived. All these can only be achieved through a skilled work force. Employees are the vital and immediately available core-competency, which the organizations should capitalise and leverage them to achieve competitive advantage.
\end{abstract}

Keywords:Turnover model; Regressions; Mobility

\section{Introduction}

Today every organization, to be effective is required to be more concerned with the questions of 'competitiveness' and 'continued existence'. A highly skilled workforce is the aorta of any organization. It is this work force that creates a sustainable competitive advantage to the organization. Innovation takes hold. New products and services are conceived [1]. All these can only be achieved through a skilled work force. Employees are the vital and immediately available core-competency, which the organizations should capitalise and leverage them to achieve competitive advantage.

Competitive advantage is "organization's unique skills and resources working to implement strategies that competitors cannot implement as effectively" [2]. Organizations are required to build talent-based competitive advantage that competitors find hard to match or duplicate (Olsen). Jack Welch, Chairman of General Electrical (GE) once said that GE's competitive edge would come from individuals and their ideas. Any forward-looking business with a desire to stay competitive must avail itself of a highly competent and reliable work-force. In particular, the software sector has changed radically and is still going through changes as new approaches and paradigms compete for dominance. Management must develop and execute value-creating initiatives quickly, talent is becoming more critical to corporate performance, specific needs for talent are more unpredictable, and companies must develop talent more rapidly than ever [3]. The retention of key strategic employees, especially managers and professionals, will determine the success or failure of an organization.

One major factor that determines the competitiveness of the organization is the labour mobility. Labour mobility has huge implications for the organization's competitiveness. The two kinds of labour mobility are: Internal mobility and External mobility. Carnicer et al. [4] stated that internal mobility was the relocation of employees within the company, known as occupational mobility and it represented a change in the assignment of job responsibilities and/or functions, and external mobility (turnover) was leaving the company, either because the employee gives up his/her job or his/her contract is cancelled. Kacmar et al. [5] stated that, for those with external job mobility, actual turnover might be an option; for those with limited external job mobility, psychological turnover (intention to quit) might be the option. It is important to know the drivers of mobility in order to improve the organization's human resource management and development.

\section{Factors Influencing Mobility}

There are two groups of factors that explain the different types of mobility: job-related and non-related factors. Job-related factors include the compensation of the remunerated work - pay and social benefits, the type of contract - permanent or temporary, and other characteristics of the job like job category or job tenure. On the other hand, job non-related factors include the employee's perception on his/ her job - like job satisfaction or work-family conflict, and demographic and personal characteristics such as gender, age or family situation.

\section{Turnover and its Type}

McEvoy and Cascio [6] defined employee turnover as movement of employee beyond the boundary of the organization. Turnover can be classified into two categories: voluntary and involuntary turnover. Voluntary turnover occurs when the employee terminates the employment relationship, involuntary turnover is when the employee wants to stay but the employer decides to terminate the relationship.

\section{Turnover Consequences}

Turnover is costly and devastating because it reduces organizational effectiveness and employee productivity [7]; causes a deterioration of rapport and trust leading to increased client dissatisfaction with agency services [8]; creates product delay in Research and Development, slows down market penetration [9]; causes poor reputation for the employers [10]. Turnover-related problems can be especially difficult in knowledge-based organizations where the productive capacity is concentrated in human capital that is, in the skills, abilities, and knowledge of employees [11]. Philliphs [12] states that turnover costs include direct expenses related to replacing an employee and indirect expenses related to loss of experience and lowered productivity. $\mathrm{He}$ also states that hidden expenses account for eighty percent or more of

*Corresponding author: Dr. Ravichandan K, Chair Person, School of Business Studies, Madurai Kamaraj University, Madurai, India, Tel: +919360505443; E-mail: ravimba.mku@gmail.com

Received May 10, 2015; Accepted May 26, 2015; Published June 06, 2015

Citation: Ravichandan K (2015) Application of Multiple Regressions in Development of an Employee Turnover Model. Int J Econ Manag Sci 4: 266. doi:10.4172/21626359.1000266

Copyright: $\odot 2015$ Ravichandan K. This is an open-access article distributed unde the terms of the Creative Commons Attribution License, which permits unrestricted use, distribution, and reproduction in any medium, provided the original author and source are credited. 
turnover costs and human efficiency is difficult to weigh, especially as productivity becomes more dependent on what is done with the mind rather than with the hands. Schlesinger and Heskett [13] describe a "cycle of failure" where high employee turnover results in low productivity, poor service, angry customers, even more discontented workers and thus, continuing high turnover. When an employee leaves, a vacancy chain is set in motion often involving the transfer of many other employees. This again disrupts the smooth working of the organization and quality defects emerge at the end of the chain with external customer effects.

\section{Turnover among Software Employees}

One of the main performance criteria is the ability to retain their manpower and thereby minimize employee turnover and this is very essential for the Indian software organizations. Indian software industry had a phenomenal growth in the last decade leading to increased job-hopping and quitting. Organizations continue to call help for this pressing issue. Agarwal [14] stated that software professionals were highly analytical and rational, looking forward to use existing knowledge, they acquired new knowledge on a continuous basis, worked on new platforms, new technologies and with new organizations. They also valued autonomy, professionalism, innovativeness and expected prompt feed-back and recognition for performance. These characteristics thus call for a software organization's human resource department to be very effective in order to retain its employees and minimize the turnover rates.

\section{Turnover intention}

Turnover intention is used instead of actual turnover because in general the Theory of Planned Behaviour. Ajzen suggests that behavioural intention is a good predictor of actual behaviour, and in particular, previous studies have successfully demonstrated that behavioural intention to leave is consistently correlated with turnover [15-18]. In fact, Mobley et al. [19] have suggested that intentions offered a better explanation of turnover because they encompassed one's perception and judgment. The propensity to quit, or more precisely the frequency of thoughts of quitting, has been identified as a predictor of voluntary labor turnover in a number of studies [20-22]. The most popular method of examining the concept is through individuals' attitudes and feelings towards his or her employing organization. It is very hard to predict the quitting behaviour of individuals without having a deeper knowledge on the behavioural process of the individuals.

Multivariate studies (approaches) are necessary in assessing turnover. Such approaches are necessary in order to interpret the relative efficacy of numerous variables and constructs that are to be related to turnover, and move towards a complete understanding of the turnover process. The main objective should be to trace the causes and define a "causal model" to predict turnover, with respect to the organizational situations. In other words the attitude measurement process should lead to defining and predicting the "Antecedents-Behaviour-Consequences" of an eventual turnover and this study focuses on studying the quitting behaviour of the software employees to develop an 'Employee Turnover Intention Model'.

\section{Development of employee turnover intention model}

Critical review of past researches helped in identification of hypotheses based on the various factors that were considered for the development of employee turnover intention model. Based on such literatures fourteen factors have been identified for the study's purpose on which the model has been derived. Ten factors were hypothesized to influence turnover intentions directly. The discussion on each factor's antecedent and decedents are discussed in relation to the development of hypotheses that formed the basis for turnover intention model.

\section{Sense of personal adequacy (PA)}

Self-esteem: Self-esteem refers to the evaluation that individuals make and customarily maintain with regard to themselves and sense of worth or value of self [23]. Low self-esteem is related to psychological problems, unemployment and maladaptive behaviour [24-26]. On the other hand high self-esteem individuals have strong, stable and positive beliefs on their qualities and self-esteem is correlated with ability, effort and satisfaction [27-30]. Demands that induce stress can diminish self-esteem [31]. Mone [32] found that "role self-esteem" increased the propensity of turnover intention in an individual.

Self-efficacy: It is employees' belief that they have the ability to cope and respond to challenging situations. Rogers [33] reported that when an individual of high self-efficacy evaluated new techniques, compatibility with knowledge, skills, ability, he/she believed that he/ she was capable of mastering the new technology. This implies that individuals with high self-efficacy is not prone to the new technology introduced in the work place, changes in culture and so on, whereby quitting due to "fear of new technology" is totally dismissed. Moore [34] reported that high self-efficacy of an individual was associated with reduced intention to quit.

Software professionals are bombarded with various external cues, which likely influence the work place behaviour but it is not so in the case of persons with high sense of personal adequacy.

H1: The employees' sense of personal adequacy will be negatively correlated with job stress.

Researches have shown the influence of personal adequacy on stress and stressors; meta-cognitions of IT workers satisfaction [35-38] "Self-esteem" and "self-efficacy" influence the turnover intentions of the employees. Employees with high level personal adequacy will be confident enough to pursue job opportunities in other organization.

H2: The software professionals' sense of personal adequacy will be positively correlated with the individual's turnover intention.

Perceived learning opportunity (PLO): Schneider [39] proposed that when employee values are congruent with those of the organization, the organization would fulfill the needs or desires of the individual and greater satisfaction and commitment could occur. Mobley et al. [19] stated that the employees evaluated the organizations future expected value with his/her work, which influenced the employees' progression through successive stages of withdrawal. Wanous et al. [40] stated that the training provided to the employees better predicted the job survival of the individual. Smith stated that when an employee's expectation regarding fulfillment of needs were met by the organization, an exchange between needs and rewards had occurred and commitment to the organization was therefore expected to increase. Learningoriented individuals see intelligence as malleable and continually seek challenge, which they believe fosters learning. They persistently examine the results of their behaviour in order to determine the best strategy for their next attempt at the same task or situation $[41,42]$. In the knowledge economy, companies are under severe pressure to cope with increasing rates of environmental change and turbulence. McHugh [43] stated that unless majority of the staff perceived that the organization developed supportive organizational mechanism to 
change, such as top management commitment, allocation of resources, rewards, training, participation in planning, change would be stressful. Perceived failure of organization to match the "professional needs" will lead to stressful misfit within the employees. When the employees need is matched, it would reduce stress and ultimately increase job satisfaction and commitment.

H3: The employees' perceived learning opportunity is negatively correlated with job stress.

Career anxiety (CA): Organizations that fail to create an opportunity for acquiring technical updates on the current technology may cause the employees to start thinking about the viability of their staying in the organization. Studies have shown that perceptions of low level of job security could result in reduced employee commitment $[44,45]$. They assert that employees who are not assured of their place in the organizational structure tend to look for security outside the organization. Anuradha Chawla and Kelloway [46] stated that job insecurity had become virtually synonymous with fear awakened by change. Loss of organizational loyalty has been proposed as result of job insecurity [47]. Employees who feel insecure about their jobs are not as likely to view their own future as bound with future of the company [48]. Ashford et al. [44] found that job insecurity was related to intention to quit. The employees would feel that quitting might help their career [49]. Employees with high growth needs may be dejected if they feel that the organization fails to update technology and keep pace with the current technological developments. Software professionals are knowledge workers. They might feel unsecured if they are not trained either on new technology or on new platforms. In both the cases the employees may view these situations as a "threat" to their career.

H4: The employees' perceived learning opportunity is negatively correlated with their level of career anxiety.

On the other hand, introduction of new technology, expecting the employees to work on a newer platform has the potential to cause stress, because the employee should develop/enhance his/her existing knowledge, skills and abilities in a short time span, which can induce stress and create career anxiety.

H5: The employees' career anxiety is positively correlated with their level of job stress.

\section{Perceived alternate employment opportunities (PAEO)}

If the employees perceive that the job alternatives are good then he/ she is likely to develop an intention to quit and more the opportunities are available, the more likely is the employee to evaluate an alternative opportunity as superior [50,51]. Michaels and Spector [52] reported that high unemployment should weaken the quit intentions- turnover pathways because many prospective leavers are reluctant to enact withdrawal intentions unless they can serve other positions elsewhere. Steel and Griffeth [53] reported a correlation of 0.13 between the perceived employment opportunity and turnover. Hulin et al. [54] contradicted that most workers do not quit on the basis of probabilities estimated from the alternatives available; they quit on the basis of certainties represented by jobs already offered. Employees might refrain from shifting jobs when appropriate opportunities are not available and thereby increase time spent at their jobs before moving on. Milliman et al. [55] reported that organization-based self-esteem concerns the degree to which individuals believe that the organization satisfy their needs and have a sense of personal adequacy in their organization. Employees with negative perception on the organization's ability to satisfy their needs may start thinking of alternate opportunities.
H6: The employees' sense of personal adequacy is positively correlated with their perceived alternate employment opportunities.

The perceived or actual alternatives constitute the ease of movement out of the organization. Matilla stated that 50 to 60 per cent of leavers arranged alternative positions before quitting. Mano-Negrin and Tzatrir [56] reported that negative perception of opportunities in the internal labor market matched by positive perceptions of external market opportunities directly affected the turnover decision-making process.

H7: The employees' perceived alternate employment opportunities are positively correlated with their turnover intention.

\section{Perceived intrinsic job characteristics (PIJC)}

Curry et al. [57] reported that work routinization strongly influenced job satisfaction. Bretz and Judge [58] found that organizational policies affected individual's assessment of the organization based on their fit with individual characteristics such as self-esteem, locus of control, need for achievement and autonomy. Stevens et al. [59] reported that more centralization would mean that power resided in a few hands and lessened individual's autonomy and prerogatives in decision-making. This results in low level of commitment. Mowday and Spencer [60] reported that high levels of autonomy and responsibility on the job were associated with low turnover. Software professionals expect autonomy in their work for producing desired output. If the employees perceive less autonomy or no autonomy, then their commitment towards the work will be influenced. When one influences the choice of work to be performed one is likely to select tasks one feels competent to address [38]. Morris and Steers [61] suggest that perceived decentralization is likely to be associated with participative decision-making and increased commitment levels through greater employee involvement. Researchers suggest a positive relationship between job autonomy and employee affective responses, such as job satisfaction and organizational commitment [62-64]. Research had stated that autonomy may contribute to a sense of commitment and loyalty to the organization through a process of reciprocation. Individuals tend to appreciate organizations that provide opportunities for decision latitude, challenge, and responsibility. They are likely to reciprocate by being more committed and loyal to the organization, as with job autonomy, experiencing a workplace that fosters personal employee development may contribute to a sense of commitment to the organization through a process of reciprocation [65].

H8: The employees' perceived intrinsic job characteristics are positively correlated with their level of commitment.

\section{Job demands (JD)}

High task (job) demands exist when individuals perceive that there is a great amount of work to be done and they must work hard and fast under time pressure [66]. Williams and Alliger [67] in their study found that task demand was negatively related to fatigue. Stevens et al. [59] found that work overload strongly influenced commitment. Role overload can be classified into qualitative and quantitative overloads. When individuals feel that they lack the necessary skills to complete an assigned task, they are considered to be experiencing qualitative overload. A quantitative "overload" is when an individual finds it difficult to complete an assigned task within a stipulated time [68-70]. High task demands exist when individuals perceive that there is a great amount of work to be done and they must work hard and fast under time pressure. The outcomes of demanding 
work include anxiety, over ability to maintain the pace of work, mental strain and fatigue [71].

H9: The employees' sense of personal adequacy is negatively correlated with their sense of job demands.

The software employees' work continuously based on targets, and quality is the noun that ought to be adhered strictly. The employees are in a great hurry to complete the task in time on or before the stipulated delivery date. Towards the end of a task or project the number of "worked hours" increases dramatically, which induces changes both physiologically and psychologically in the employees.

H10: The employees' perception on their job demand is positively correlated with their perceived level of stress.

\section{Work stress (WS)}

Job stress refers to a situation wherein job-related factors interact with the worker to change his/her physiological and/or psychological conditions such that the person is forced to deviate from the normal functioning [72]. One factor that has been associated with both work attitudes and turnover intention is job stress. Kahn and Byosiere [73] states that "many variables become stressors not only when present in excess but also when lower than optimum level". Too much and too little work induces stress. McGrath [74] states that stress is an out-balance situation where demands do not match the individuals capabilities. French and Caplan [75] indicate that career progress stress adversely impacts job satisfaction. The potential career progress stressors also include lack of job security and technology obsolescence. Career progress stress is based on lack of opportunity to advance. Stress related problems among workers contribute to dysfunctional organizational consequences such as decreased commitment, increased absenteeism and high turnover [76]. Fisher and Gitelson [77] state that role stress is negatively related to job satisfaction.

H11: The employees' sense of perceived job stress is negatively correlated with their level of job satisfaction.

H12: The employees' level of perceived job stress is positively correlated with their level of turnover intention.

\section{Burnout (BO)}

Laschinger et al. [78] indicate that burnout is a phenomenon commonly associated with levels of autonomy namely lack of control, over-work practices and lack of organizational trust. Mattenson and Ivancevich [79] report that anything that causes job stress may contribute to burnout. Bhanugopan and Fish [80] state that when people describe themselves experiencing 'job burnout' they are most likely to refer to an exhaustion which is the central quality of job burnout. Houkes et al. [81] reported that emotional exhaustion was primarily predicted by high workload and lack of social support. Any individual can experience "job burnout" so long as he/she has run for stress in his/her work life. Many of today's workers are finding their jobs more stressful because they are working too many hours. Studies report that "where employees are empowered, where they have more control on how they perform their work, the risk of stress and burnout is less $[82,83]$.

H13: The employees' sense of perceived job stress is positively correlated to with their level of job burnout.

An organizational culture that becomes too stressful, nonchallenging with its employees' needs and desires may lead to personal burnout and higher turnover rates. Jackson and Schuler [84] report that, although burnout and other affective reactions are strongly linked to a desire to leave, intentions to leave may not become translated into actions since the process is very complex and includes many intermediate linkages such as low probability of finding another job on the same pay. Burnout can include withdrawal and decreasing involvement in the job, seriously affecting job satisfaction, turnover, absenteeism, and productivity [85,87].

H14: The employees' level of burnout is negatively correlated with their sense of job satisfaction.

\section{Fit perceptions (FP)}

PJ fit results in high job proficiency; work is likely to be accomplished quickly and with higher ability quality than in circumstances when the job proficiency is low. This in turn, improves organizational effectiveness. PG fit is conducted at the group level analysis. PG fit is likely to impact organizational effectiveness by promoting group cooperation and synergy. PO fit is conducted at the organizational level. It concerns the match between the worker and the organization culture. Kristof [88] reported that PO fit improves work attitudes and retention rates.

Silver thorne [24] reported that a good fit is a powerful variable within the organization and it has a positive impact on job satisfaction and organizational commitment and negative impact on turnover rates. The better the fit the higher the organizational commitment and lower the turnover rate. Studies have shown that positive perceptions of fit can have long term consequences for one's career [89,90].

Argyris argues that a great deal of organizational outcomes depend on the degree of congruence between individual characteristics and those of the organization. Study conducted by Ahluburg et al. [91] reported that the person-job fit, person-organization fit, and persongroup fits were related to job satisfaction (satisfaction with the workitself, supervisor, and coworkers), organizational commitment, and withdrawal from the job. Studies have shown that positive perceptions of fit can have long term consequences for one's career. Software employees' work in teams and cohesion is an important factor that should exist as the work is hugely based on knowledge sharing. They tend to be more innovative and receptive towards gaining knowledge and they like to have a challenging task. In general, the organization should match the expectations of the individuals and if the organization fails to do so then it will be detrimental to the employees' behaviour.

H15: The employees' perceived learning opportunity is positively correlated with their fit perceptions.

H16: The employees' perceived fit perceptions are positively correlated with their turnover intention.

\section{Pre-employment expectations (PEE)}

Role conflict deals with difference between an individual's expectation of the job and the reality of the job [92]. The software professionals' behaviour is based on the "met-expectations" of their jobs in terms of tasks, rewards, career growth and other advancements.

H17: Employees' pre-employment expectation is positively correlated with their level of satisfaction and negatively related with their level of turnover intention.

\section{Perceived inequity (PI)}

Cascio [93] states that employees who cannot achieve an acceptable "adjustment" of the input: outcome ratios, either in reality 
or by altering perception of the ratio, typically resolve the situation by withdrawing from the organization. In the performance appraisal context, distributive justice refers to the fairness of the evaluation received, whereas procedural justice refers to the fairness of the process used in determining the evaluation and in this study the distributive justice is considered to evaluate the employees perceived in equity. The Adam's equity theory was applied with employees' perceived equity on payments and rewards when compared to employees of equal status within their organization (internal perceived equity) and also outside the organization that is with the employees of other organizations (external perceived equity).

H18: The employees' internal perceived inequity is negatively related with their commitment and negatively related with their turnover intention.

H19: The employees' external perceived inequity is negatively related with their commitment and negatively related with their turnover intention.

\section{Organizational commitment (Comm)}

Consequences of commitment vary according to individuals' level of attachment [94]. Organizational commitment remains an important and valuable attitude for an organization [95]. Attitudinal commitment is measured in this study. Various studies have found a strong support of negative relationships between organizational commitment and turnover $[22,96,97]$. Number of models exist linking commitment to turnover $[19,98]$ and intent to turnover $[99,100]$. Employees who left the organization within a short span of time showed a definite decline in commitment prior to termination [42]. It is important for an organization to keep their employees committed. It is believed that a proper alignment of resources can act as a motivational tool for the organization, enhancing the employees' sense of commitment and loyalty. Individuals allowed to build on their personal adequacy should feel better towards organization and can share common goals and values, which is similar to Scholls' [101] general model of stability of behaviour. It states that behaviour is based on expectancy and commitment proposition. Expectancy proposition is the propensity to remain in a particular organization which increases, as the individual's perceived probability of continued equitable rewards associated with continued membership increases. Commitment proposition is the propensity to remain in a particular organization which increases as individuals' investment to that organization increases, alternative opportunities become blocked through the acquisition of skills specific to that organization and the individuals' social identity become tied to that organization. If individuals fail to perceive positive probabilities they may start to blame and seriously start thinking about quitting.

H20: The employees' sense of personal adequacy is positively correlated with their level of organizational commitment.

H21: The employees' level of commitment is negatively correlated with their turnover intention.

Bateman and Strasser [102] found that organizational commitment was an antecedent to job satisfaction. Marsh and Mannari [103] found satisfaction as the antecedent of commitment. This can be accomplished by providing opportunities for the employees to succeed and by satisfying their growth needs. Brown and Peterson [104] state that employees who possess high levels of job satisfaction are ought to have stronger commitment to organization. Igbaria and Guimaraes [105] in their study confirmed the important role of organizational commitment in the turnover process for IT personnel. They stated also that Information Technology (IT) employees who were highly committed to their organization were less likely to leave than those who are relatively uncommitted. If the organization makes the employees feel good about them, the level of organizational commitment will increase.

H22: The employees' sense of job satisfaction will be positively correlated to their level of organizational commitment.

\section{Loyalty (Loy)}

There is a difference between loyalty and organizational commitment. Loyalty is a strong desire to maintain a relationship with the organization but commitment is a strong belief and acceptance of organizational goals and values. Studies have shown loyalty as an antecedent to turnover intentions and influenced commitment $[106,107]$. Results of overall rewards of work study conducted by Sibson [108] support the link between low engagement and high turnover rates and high satisfaction among the highly engaged workers with lesser turnover rates.

It is widely recognized that knowledge workers exhibit greater loyalty to their profession and colleagues than to their employing organizations [109]. Hence it is important for the organizations to increase the level of loyalty through commitment. Commitment towards the organization results from the maximization of human resources and increasing employee loyalty, and this in turn results in less absenteeism from the work place and lower labor turnover.

H23: The employees' sense of organizational commitment is positively correlated with their level of organizational loyalty.

H24: The employees' sense of organizational loyalty is negatively correlated with their turnover intention.

\section{Job satisfaction (Sat)}

Job satisfaction is generally recognized as a multifaceted construct that includes employee feelings about a variety of both intrinsic and extrinsic job elements. It encompasses specific aspects of satisfaction related to pay, benefits, problem, work and relationship with co-workers [110]. Researches stated the importance of work characteristics (routine, autonomy and feedback), characteristics of the work environment (leadership, stress, advancement, opportunities and participation) in relation to job satisfaction $[111,112]$. Studies found that employees who left the organization had less satisfaction on five or seven job dimensions (Satisfaction with the management, pay, work, promotion and supervision) and propensity to leave $[113,114]$.

H25: The employees' sense of personal adequacy is positively correlated with their level of job satisfaction.

Those who have the intention of quitting should demonstrate less satisfaction with their employers, believing that the organization is no longer able to provide that which they expect from their jobs [115]. Self consistency theory states that employees will develop attitudes about their job satisfaction that are consistent with their selfesteem. If incongruence exists then dissatisfaction occurs.

Employees who experience job satisfaction are more likely to stay on the job $[116,117]$ and likely to be productive. Several studies show negative relationship between job satisfaction and turnover [118-121]. Numerous researches show the negative relationship between job satisfaction and turnover intention [122-125]. 
H26: The employees' sense of job satisfaction is positively correlated with their level of organizational commitment.

\section{Turnover intention (TI)}

The propensity to quit or more precisely the frequency of thoughts of quitting, has been identified as a predictor of voluntary labor turnover in a number of studies [16,52,126-128]. Mobley et al. [19] states that actual turnover is expected to increase as in the intention to quit increases.

H27: The employees' sense of job satisfaction is negatively correlated with their turnover intention.

\section{Demography}

Personal variables such as age, gender, job tenure, educational level, marital status have been researched and shown to be relevant to commitment, satisfaction and turnover intentions [129-134]. Age is perhaps the most consistent individual characteristics variable with its reported negative and significant relationship to turnover and education positively related to turnover [35]. Given the composition of the workforce, the relationships will be determined. Based on the proposed hypotheses a turnover intention model was developed. Figure 1 shows the hypothesized model for validation.

\section{Method}

\section{Participants and procedures}

Total of four hundred and nine employees from three software organizations participated in the study; 282 (approx. 69 percent) were males and 127 (31 percent) were females. The majority of the participants (70 percent) were between 22 and 27 years of age and 74 per cent of the participants had 10 months to 6 years of work experience. The overall mean age and the mean tenure of the female respondents were 25.99 and 3.27 with a standard deviation of 2.56 and 1.82, respectively. The mean age and the mean tenure of the male respondents were 26.41 and 3.64 with standard deviations of 2.74 and 2.32 respectively A total of 188 (46 percent) were married and 221 (54 percent) were single. Regarding the participants educational background, 220 (54 percent) were undergraduates (both from professional and non-professional courses); 155 (37percent) were post graduates and the remaining 34 (9 percent) had other degrees.

\section{Instrument design}

Participants completed a self-reporting questionnaire, which incorporated sixteen factors viz, Sense of Personal Adequacy (scale modified by Wendell) [135]; Perceived Learning Opportunity (statements from Useem); Career Anxiety; Perceived Alternate Employment Opportunity (scale items adapted from Michaels and Spector; Arnold and Feldman, and Mowday et al. [52,136]. Perceived Intrinsic Job Characteristics (scale developed by [57]; Job Demand (Scale developed by Van Yperen and Janssen); Work Stress (scale developed by Behson); Burnout (Measures developed by Pines and Aronson [70]); Fit Perceptions-Person-job; Person-organization; Person-group [137-139]. Pre-Employment Expectations (scale developed by the researchers); Perceived Inequity-Internal and External (scale developed by the researchers); Organizational Commitment (OCQ by Porter et al. [126]); Organizational Loyalty (statements from Mac and Sockel); Job Satisfaction (statements from Mac and Sockel); Opinion on previous employment scale developed by the researchers); and Turnover Intention [140], that were either directly or indirectly related to the study on turnover intention. In addition, personal and demographic data related to age, gender, marital status, educational background, work experience and dependency were also collected.

A pilot study was conducted to measure the reliability of the questionnaire. Items were eliminated from the instrument if they failed to singularly load. A few scale items were removed after the pilot study of the questionnaire. Post pilot study the questionnaire consisted of 120 statements in total. The questionnaire was constructed and sequenced logically for the convenience of the respondents. To encourage the respondents to provide their response without any fear and to create trust a covering letter was attached indicating the purpose of the study, and the promise of confidentiality. Respondents were briefed on the general purpose of the study, and asked to complete the questionnaire without any fear.

\section{Results}

\section{Inter correlation report among the various constructs}

A two-tail Pearson's correlation was applied between all the constructs. Table 1 is the report of the zero order correlations between the various constructs. A positive value indicates that increase in one variable increases the other variable too. A negative value indicates that increase in one variable decreases the other variable. The supported hypotheses of the proposed model (model for validation) are in bold print and those hypotheses that were not supported are italicized. The relationships that were unanalyzed, which can be used for further analyses are in bold print and underlined.

\section{Model validation}

Simultaneous regression was used to examine the unique effects of each independent variable on a dependent variable and at the same time to validate the hypothesized model (Figure 1). This method identifies the amount of unique variable contributed by each independent variable after the shared variance of the independent variable is removed.

The scale items of each construct were averaged together to form a single non-weighted average value. These averages were used in the simultaneous regression technique to study the support of relationship for the hypothesized model. The testing of the hypothesized model was carried in nine stages. The model was tested through the iterative approach working from 'right side' to 'left side' of the hypothesized model. The first stage used turnover intention (TI) as dependent variable with personal adequacy (PA), perceived alternate employment opportunities (PAEO), work stress (WS), fit perceptions (FP), preemployment expectations (PEE), perceived inequity-internal (PIE-I), perceived inequity-external (PIE-E), loyalty (Loy), commitment (Comm) and satisfaction (Sat) as independent variables. The construct perceived learning opportunities, pre-employment expectations, perceived intrinsic job characteristics, perceived inequity-internal and perceived inequity-external were the exogenous variables. Table 2 details the treatment of variables at each stage.

\section{Model significance testing}

If the associated ' $\mathrm{p}$ ' value for overall $\mathrm{F}$ at each stage is less than 0.05 levels then the result suggests that the overall regression model at that stage is statistically significant. An independent variable was considered to significantly influence the dependent variable if that particular independent variable's $p$ value was found to be less than 0.05 levels. The regression was run twice. A second run regression was performed for those independent variables, which were found to be significant during 
Citation: Ravichandan K (2015) Application of Multiple Regressions in Development of an Employee Turnover Model. Int J Econ Manag Sci 4: 266. doi:10.4172/21626359.1000266

Page 7 of 18

\begin{tabular}{|c|c|c|c|c|c|c|c|c|c|c|c|c|c|c|c|c|}
\hline Constructs & 1 & 2 & 3 & 4 & 5 & 6 & 7 & 8 & 9 & 10 & 11 & 12 & 13 & 14 & 15 & 16 \\
\hline 1.PA & 1 & & & & & & & & & & & & & & & \\
\hline 2.PLO & $0.193^{* *}$ & 1 & & & & & & & & & & & & & & \\
\hline 3.CA & $-0.392^{* *}$ & $-0.344^{\star *}$ & 1 & & & & & & & & & & & & & \\
\hline 4.PAEO & $0.465^{\star *}$ & 0.072 & $-0.193^{* *}$ & 1 & & & & & & & & & & & & \\
\hline 5.PIJC & $0.573^{* *}$ & $0.230^{\star *}$ & $-0.295^{\star \star}$ & 0.252 & 1 & & & & & & & & & & & \\
\hline 6.JD & -0.047 & 0.01 & 0.021 & -0.007 & 0.089 & 1 & & & & & & & & & & \\
\hline 7.WS & $-0.129 * *$ & $-0.112^{*}$ & 0.054 & -0.044 & 0.041 & $0.760^{* *}$ & 1 & & & & & & & & & \\
\hline 8.BO & $-0.191^{* *}$ & -0.051 & 0.058 & -0.072 & 0.008 & $0.354^{* *}$ & $0.476^{* *}$ & 1 & & & & & & & & \\
\hline 9.FP & $0.146^{* *}$ & 0.079 & -0.039 & 0.074 & $-0.112^{*}$ & $-0.273^{* *}$ & $-0.364^{* *}$ & $-0.258^{* *}$ & 1 & & & & & & & \\
\hline 10.PEE & $0.150^{* *}$ & 0.044 & -0.007 & $0.104^{*}$ & -0.018 & $-0.152^{* *}$ & $-0.186^{\star *}$ & $-0.130^{* *}$ & $0.470^{* *}$ & 1 & & & & & & \\
\hline 11.PIE-I & $-0.198^{* *}$ & -0.078 & $0.099^{*}$ & -0.095 & $-0.0178^{* *}$ & 0.082 & $0.159^{* *}$ & $0.147^{* *}$ & -0.052 & 0 & 1 & & & & & \\
\hline 12.PIE-E & 0.004 & -0.023 & 0.022 & -0.069 & -0.037 & -0.079 & -0.027 & -0.042 & $0.207^{* *}$ & $0.215^{\star *}$ & $0.377^{* *}$ & 1 & & & & \\
\hline 13.Loy & $0.196^{\star *}$ & -0.005 & -0.056 & 0.083 & -0.005 & $-0.304^{* *}$ & $-0.357^{* *}$ & $-0.285^{\star *}$ & $0.429^{* *}$ & $0.332^{* *}$ & 0.017 & $0.304^{* *}$ & 1 & & & \\
\hline 14.Comm & $0.226^{* *}$ & 0.055 & -0.083 & $0.104^{*}$ & 0.086 & $-0.267^{* *}$ & $-0.275^{\star *}$ & $-0.193^{* *}$ & $0.257^{\star *}$ & $0.214^{* *}$ & $-0.292^{\star *}$ & 0.005 & $0.490^{* *}$ & 1 & & \\
\hline 15.Sat & $0.220^{\star *}$ & $0.126^{*}$ & $-0.120^{*}$ & 0.079 & 0.092 & $-0.422^{* *}$ & $-0.560^{\star *}$ & $-0.432^{\star *}$ & $0.333^{\star *}$ & $0.244^{* *}$ & $-0.203^{\star *}$ & $0.148^{* *}$ & $0.458^{\star *}$ & $0.440^{\star *}$ & 1 & \\
\hline 16.TI & -0.066 & -0.002 & -0.009 & -0.003 & $0.111^{*}$ & $0.471^{* *}$ & $0.544^{* *}$ & $0.344^{\star *}$ & $-0.438^{* *}$ & $-0.267^{\star *}$ & $0.118^{*}$ & $-0.147^{* *}$ & $-0.600^{* *}$ & $-0.492^{\star *}$ & $-0.583^{* *}$ & 1 \\
\hline$N=409$ & & & & & & & & & & & & & & & & \\
\hline
\end{tabular}

Note: $\mathrm{PA}=$ Personal adequacy; $\mathrm{PLO}=$ Perceived learning opportunity; CA=Career anxiety; PAEO=Perceived alternate employment opportunity; PIJC=Perceived intrinsic job characteristics; JD=Job demands; WS=Work stress; BO=Burn out; FP=Fit perceptions; PEE=Pre-employment expectation; PIE-I =Perceived inequity-internal; PIE-E= Perceived inequity-external; Loy=Loyalty; Comm=Commitment; Sat=Satisfaction; Tl=Turn over intention. *significant at 0.05 level; ** significant at 0.01 level.

Table 1: Inter-Correlation report.

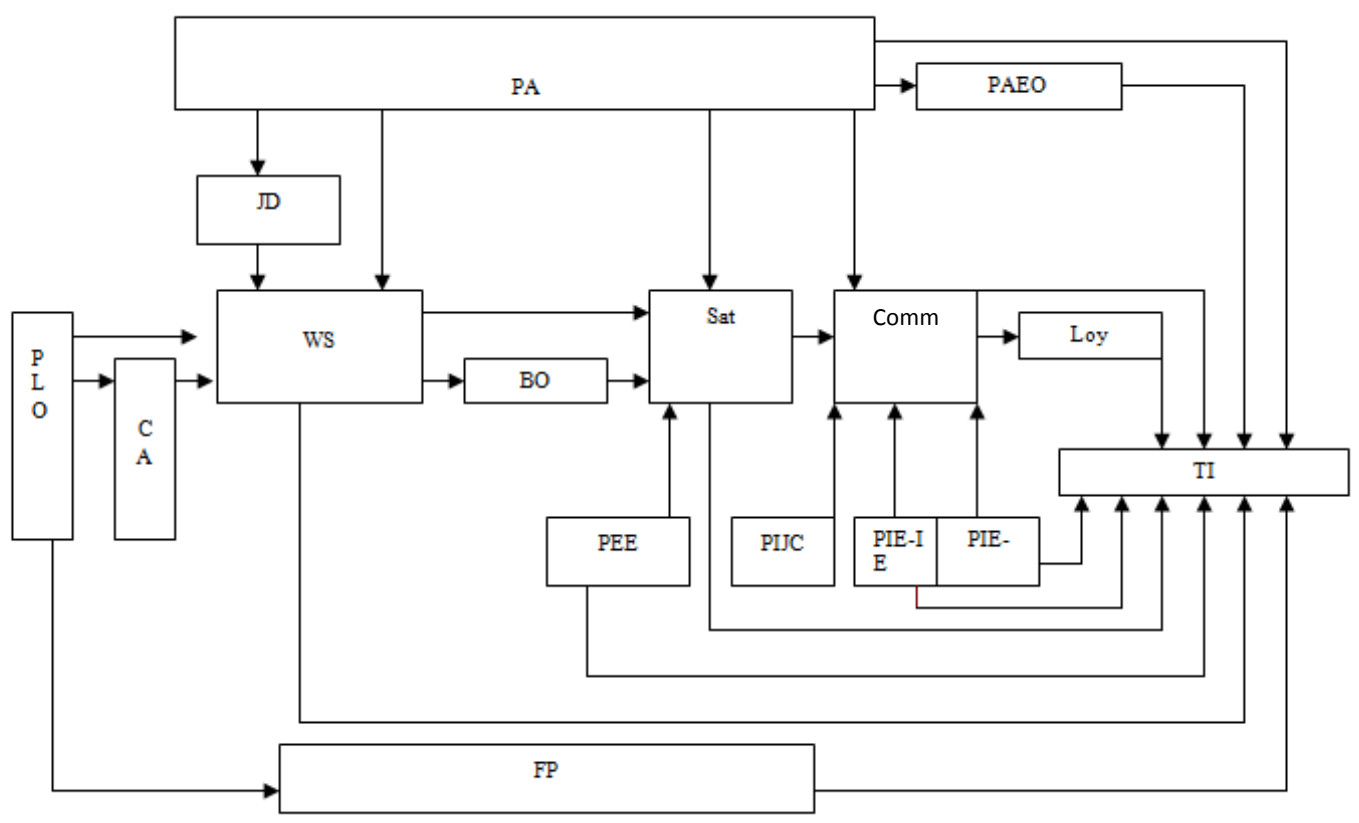

Figure 1: Conceptual model for organizational flexibility.

the first run of simultaneous regression. Stage-wise the regression results are provided. Table 3 is the summarized results of the first run regression.

The Table 3 shows that during the first run regression; personal adequacy, work stress, fit perception, loyalty, commitment and satisfaction were found to be significantly influencing the turnover intention in the first stage and the model (Adjusted R2=0.561) was also found to be significant. In stage two, the effect of commitment's (independent variable) influence on loyalty was examined; it was found that the model was significant, adjusted $R 2=0.24, F(1,407)=128.52$, $\mathrm{p}<0.001$. Commitment influenced loyalty. During stage three the simultaneous effects of personal adequacy, perceived intrinsic job characteristics, perceived inequity-internal, perceived inequityexternal and satisfaction (independent variables) on commitment (dependent variable) were examined. The result revealed that the model was significant, adjusted R2 $=0.241, \mathrm{~F}(5,403)=28.87, \mathrm{p}<0.001$ and the independent variables, personal adequacy, perceived inequity-internal, and satisfaction significantly influenced commitment. The simultaneous 


\begin{tabular}{|c|c|c|}
\hline Stage & Dependent Variable & Independent Variable \\
\hline Two & Loyalty & Commitment \\
\hline Three & Commitment & $\begin{array}{c}\text { Personal adequacy } \\
\text { Perceived intrinsic job } \\
\text { characteristics } \\
\text { Perceived inequity- } \\
\text { internal } \\
\text { Perceived inequity- } \\
\text { external } \\
\text { Satisfaction }\end{array}$ \\
\hline Four & Satisfaction & $\begin{array}{l}\text { Personal adequacy } \\
\text { Work stress } \\
\text { Burn out } \\
\text { Pre-employment } \\
\text { expectations }\end{array}$ \\
\hline Five & Burn out & Work stress \\
\hline Six & Work stress & $\begin{array}{l}\text { Personal adequacy } \\
\text { Perceived learning } \\
\text { opportunity } \\
\text { Career anxiety } \\
\text { Job demands }\end{array}$ \\
\hline Seven & Fit perception & $\begin{array}{c}\text { Perceived learning } \\
\text { opportunity }\end{array}$ \\
\hline Eight & $\begin{array}{l}\text { Perceived alternate } \\
\text { employment opportunities }\end{array}$ & Personal adequacy \\
\hline Nine & Career anxiety & $\begin{array}{l}\text { Perceived learning } \\
\text { opportunity }\end{array}$ \\
\hline
\end{tabular}

Table 2: Treatment of variables at each stage.

effects of independent variables (personal adequacy, work stress, burnout, and pre-employment expectations) on the dependent variable (satisfaction) were examined in during the fourth stage regression run. The result revealed that personal adequacy, work stress, burnout, and pre-employment expectations significantly influenced satisfaction and the model was also found be significant with adjusted $\mathrm{R} 2=0.372$ and $\mathrm{F}$ $(4,404)=61.44, \mathrm{p}<0.001$.

In stage five the effect of work stress (independent variable) was examined on job burnout (dependent variable) and was found to be significantly influenced by work stress.

Stage six analyzed the effects of independent variables (personal adequacy, perceived learning opportunity, career anxiety and job demands) on the dependent variable (Work Stress). The result showed that the model was found to be significant, adjusted R2 $=0.594, \mathrm{~F}(4,404)$ $=150.338, \mathrm{p}<0.001$. Personal adequacy, perceived learning opportunity and job demands significantly influenced work stress. Stage seven, eight and nine had only one independent variable to be regressed on the dependent variable. Stage seven had perceived learning opportunity as independent variable and fit perception as dependent variable. Stage eight had personal adequacy as independent variable and perceived alternate employment opportunities as dependent variable. Stage nine had perceived learning opportunity as independent variable and career anxiety as dependent variable. The model resulted in the stage seven was insignificant, adjusted $R 2=0.003, F(1,407)=2.068, p>0.05$. The model that resulted from stage eight adjusted $\mathrm{R} 2=0.214, \mathrm{~F}(1,407)=112.27$, $\mathrm{p}<0.01$ and the model from stage nine, adjusted $\mathrm{R} 2=0.118, \mathrm{~F}$ $(1,407)=54.52, p<0.001$ were found to be significant. Perceived alternate employment opportunity was significantly influenced by personal adequacy. Career anxiety was significantly influenced by the perceived learning opportunity.

\section{Regression analysis-second run}

The independent variables that were found significant during the simultaneous regression were considered for second run in the multiple regressions. The second run of simultaneous regression was carried out only with those independent variables that were found to be significant during the first run. The second run regression was carried for stages one, three, four and six. The other stages were not considered for a second run-regression because those stages had only one independent variable with them. Table 4 shows the second-run regression results.

From the Figure 2, it can be inferred that perceived adequacy failed to influence the job demands. Though career anxiety was determined by perceived learning opportunities, the career anxiety failed to explain the work stress. Similarly high sense of personal adequacy leads to high perception in the alternatives available, but PAEO failed to explain turnover intentions. Hence, career anxiety and PAEO were removed from the original model. PIJC failed to explain commitment and PIE-E failed to explain commitment and turnover intentions. PIE-I did not influence TI but it influenced commitment. PEE explained satisfaction but did not explain TI. PLO failed to explain fit perceptions. Thus the exogenous variables of the trimmed model were JD, PA, PLO, FP, PEE and PIE-I. Figure 3 shows the model with supported relationships with its respective beta weights.

There were six constructs in the model (Figure 3) that can be classified as exogenous factors. The affecting variables of the exogenous factors are unknown. Hence, relationships were established between the exogenous and the other endogenous variables. Pearson correlation Table 1 showed significant relationship between fit perceptions and job demands; personal adequacy and pre-employment expectations; between perceived learning opportunities, perceived intrinsic job characteristics and fit perceptions. To test these relationships separate stages of regression were performed to determine the significant influence because correlation does not explain causation. Those variables for which no relationships could be found were omitted from the study. The Figure 4 shows the newly added paths in the validated model.

New paths are presented in dotted line (Figure 4). These new paths were included to avoid any kind of inclusion that may be an important variable for the study. Career anxiety when simultaneously regressed with the other independent variables of satisfaction, it was found that career anxiety neither increased nor decreased the adjusted R2 value. When career anxiety was regressed alone with the dependent variable, satisfaction, it accounted for a minimal variance. The newly added paths relationship was weak in explaining the variance. Hence, these new paths were not considered for further analysis of the model.

\section{Alternate model}

A good model is one, which increases the predictive path. A good model development stops where its predictive path is at the highest. All the new paths defined either had a weak explained variance or no causation. The new paths in no way either increased or decreased the R2 values. Hence, the new paths were omitted from the model. In the correlation Table 1, the relationship between satisfaction and loyalty was found to be significant. To increase the explanatory power of the model it was decided to swap the positions of loyalty and commitment in the model without affecting the impact of its endogenous variables and without much affecting the hypotheses of the model. The reason for swapping loyalty and commitment in the model was to find if any increase in the R-square could be obtained, whereby the model development can be stopped without any further alterations.

The change that took place in the relationship between loyalty, commitment and turnover intention was that before swapping, loyalty 
Citation: Ravichandan K (2015) Application of Multiple Regressions in Development of an Employee Turnover Model. Int J Econ Manag Sci 4: 266. doi:10.4172/21626359.1000266

Page 9 of 18

\begin{tabular}{|c|c|c|c|c|c|c|c|c|}
\hline \multirow[t]{2}{*}{ Stage } & \multirow[t]{2}{*}{ D.V } & \multirow[t]{2}{*}{ I. $\mathrm{V}$} & \multicolumn{2}{|c|}{ Un standardised } & \multirow{2}{*}{$\begin{array}{c}\text { Standardised } \\
\text { coefficients }\end{array}$} & \multirow[t]{2}{*}{ t-value } & \multirow[t]{2}{*}{ Anova (F) } & \multirow[t]{2}{*}{ Adj. $R$} \\
\hline & & & Beta & Std.error & & & & \\
\hline & \multirow[t]{11}{*}{$\mathrm{TI}$} & Constant & 4.716 & 0.296 & & 15.938 & \multirow[t]{11}{*}{$53.114^{* * *}$} & \multirow[t]{11}{*}{0.561} \\
\hline & & PA & 0.138 & 0.44 & 0.121 & $3.141^{* *}$ & & \\
\hline & & PAEO & 0.026 & 0.046 & 0.021 & 0.577 & & \\
\hline & & WS & 0.178 & 0.032 & 0.231 & $5.611^{\star \star \star}$ & & \\
\hline & & FP & -0.143 & 0.0046 & -0.128 & $-3.139^{* *}$ & & \\
\hline & & PEE & 0.005 & 0.029 & 0.007 & 0.190 & & \\
\hline & & PI-I & 0.004 & 0.029 & 0.005 & 0.137 & & \\
\hline & & $\mathrm{PI}-\mathrm{E}$ & 0.006 & 0.029 & 0.009 & 0.237 & & \\
\hline & & LOY & -0.271 & 0.039 & -0.303 & $-6.871^{* * *}$ & & \\
\hline & & COMM & -0.19 & 0.044 & -0.178 & $-4.303^{* * *}$ & & \\
\hline & & SAT & -0.214 & 0.042 & -0.225 & $-5.064^{* * *}$ & & \\
\hline \multirow[t]{2}{*}{ Two } & \multirow[t]{2}{*}{ Loy } & Constant & 1.614 & 0.813 & & 8.802 & \multirow[t]{2}{*}{$128.52^{* * *}$} & \multirow[t]{2}{*}{0.238} \\
\hline & & COMM & 0.586 & 0.052 & 0.490 & $11.337^{\star * *}$ & & \\
\hline \multirow[t]{6}{*}{ Three } & \multirow[t]{6}{*}{ Comm } & Constant & 2.494 & 0.249 & & 10.02 & \multirow[t]{6}{*}{$28.87^{* \star *}$} & \multirow[t]{6}{*}{0.241} \\
\hline & & PA & 0.149 & 0.058 & 0.140 & $2.593^{*}$ & & \\
\hline & & PIJC & -0.078 & 0.064 & -0.065 & -1.235 & & \\
\hline & & $\mathrm{PI}-\mathrm{I}$ & -0.150 & 0.035 & -0.211 & $-4.282^{* * *}$ & & \\
\hline & & PI-E & 0.018 & 0.033 & 0.027 & 0.561 & & \\
\hline & & SAT & 0.329 & 0.041 & 0.368 & $7.971^{\star \star \star}$ & & \\
\hline \multirow[t]{5}{*}{ Four } & \multirow[t]{5}{*}{ Sat } & Constant & 4.084 & 0.237 & & 17.261 & \multirow[t]{5}{*}{$61.44^{* * *}$} & \multirow[t]{5}{*}{0.372} \\
\hline & & PA & 0.131 & 0.048 & 0.110 & $2.723^{\star *}$ & & \\
\hline & & WS & -0.350 & 0.036 & -0.433 & $-9.608^{* * *}$ & & \\
\hline & & BO & -0.191 & 0.045 & -0.189 & $-4.196^{\star \star *}$ & & \\
\hline & & PEE & 0.099 & 0.033 & 0.122 & $3.040^{\star *}$ & & \\
\hline \multirow[t]{2}{*}{ Five } & \multirow[t]{2}{*}{ BO } & Constant & 1.726 & 0.097 & & 17.723 & $118.91^{\star \star \star}$ & 0.224 \\
\hline & & WS & 0.382 & 0.035 & 0.476 & $10.905^{\star \star \star}$ & & \\
\hline Six & WS & Constant & 0.698 & 0.330 & & 2.111 & $150.33^{* * *}$ & 0.594 \\
\hline & & PA & -0.124 & 0.051 & -0.84 & $-2.445^{\star}$ & & \\
\hline & & PLO & -0.151 & 0.044 & -0.115 & $-3.41^{* *}$ & & \\
\hline & & $\mathrm{CA}$ & 0.05 & 0.053 & -0.034 & -0.942 & & \\
\hline & & JD & 0.97 & 0.040 & 0.758 & $24^{\star \star *}$ & & \\
\hline Seven & FP & Constant & 3.41 & 0.127 & & 1.438 & 2.068 (N.S) & 0.003 \\
\hline & & PLO & 0.064 & 0.045 & 0.07 & 1.438 & & \\
\hline Eight & PAEO & Constant & 1.975 & 0.127 & & 15.526 & $112.27^{\star \star \star *}$ & 0.216 \\
\hline & & PA & 0.0425 & 0.040 & 0.465 & $10.596^{* \star *}$ & & \\
\hline Nine & $\mathrm{CA}$ & Constant & 3.909 & 0.041 & & 33.585 & $54.52^{* \star *}$ & 0.116 \\
\hline & & PLO & -0.304 & 0.041 & -0.344 & $-7.384^{\star \star \star}$ & & \\
\hline
\end{tabular}

Table 3: Summarized results of first run regression with significant predictors.

was directly related to the turnover intention and commitment was related to turnover intention in both ways that is both direct and indirect. The indirect effect was through loyalty. In the proposed alternate model (Figure 5) commitment was directly related to turnover intention and it had no indirect relationship. Instead, loyalty had indirect effect on turnover intention through commitment and direct effect on turnover intention. Loyalty was influenced by satisfaction. The effect of loyalty on turnover intention and the effect of commitment on turnover intention did not change irrespective of the positions they held, because those two variables were directly related to turnover intention The major change was satisfaction influencing loyalty instead of commitment influencing loyalty and this particular relationship, 'satisfaction to loyalty" is the only addition to new path construction (Table 5).

The influence of independent variables which had loyalty as one of the commitments' predictors was found to determine the changes in the explained variance, that is, the changes in the R2. The Table 6 shows the simultaneous influence of personal adequacy, perceived inequityInternal, satisfaction and the newly added independent variable 'loyalty'.

From the Table 6 it can be inferred that the model was found 


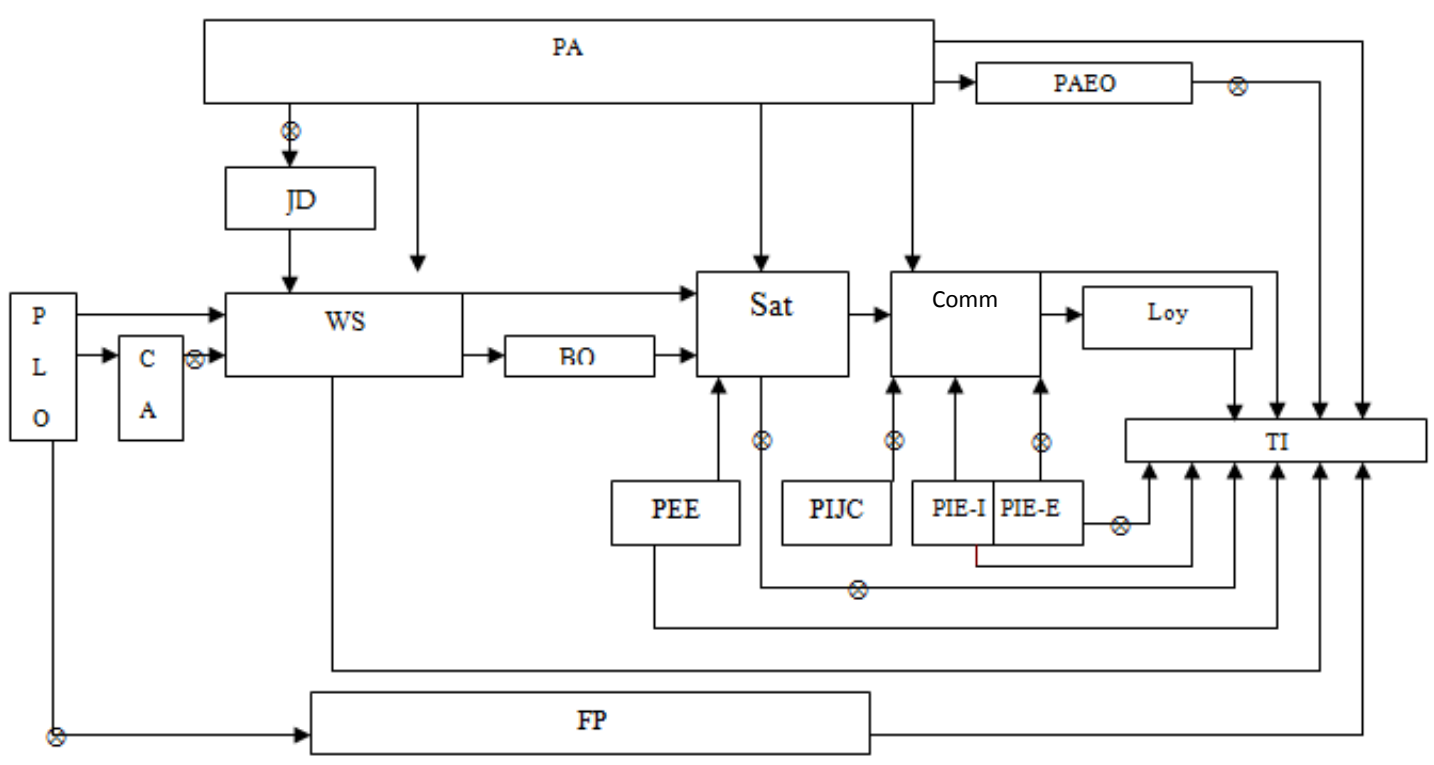

$\otimes$ - Hypothesis not supported.

Figure 2: Validated model with supported relationships.

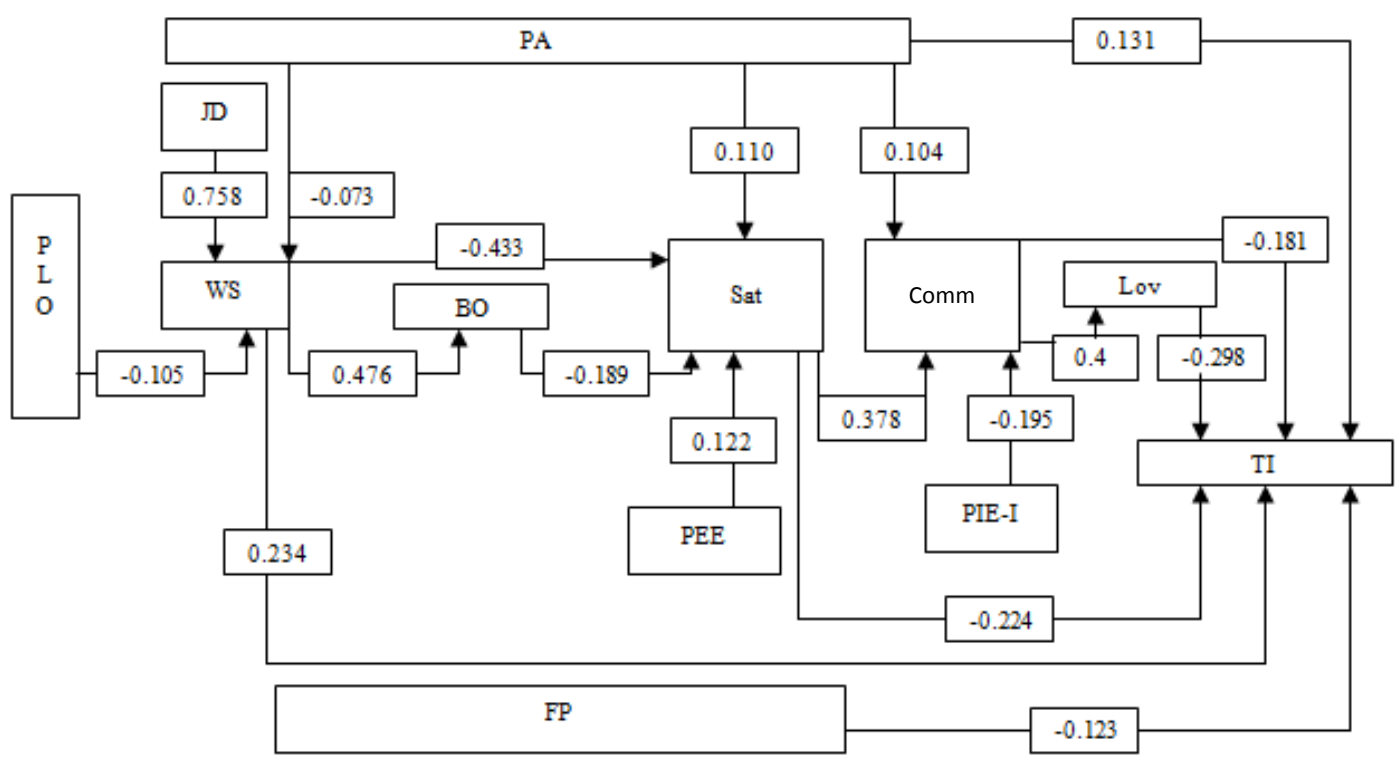

Figure 3: Validated model with its beta weights.

to be significant, adjusted $\mathrm{R} 2=0.358, \mathrm{~F}(4,404)=57.917, \mathrm{p}<0.001$. Independent variables perceived inequity-internal, satisfaction and loyalty significantly influenced commitment. Table 7 compares the independent variable coefficients (Standardized) on commitment between the final model and the alternate model.

From the Tables 7 and 8 it is found that there was an increase in the ' $R$ ' measures. The alternate models' $R 2$ had increased by 0.117 from 0.247 to 0.346 and the adjusted $\mathrm{R} 2$ had increased from 0.241 to 0.358 , a difference of 0.117 which was a significant increase. It was also inferred that the personal adequacy failed to influence commitment when loyalty was included as one among the independent variables. There were no changes in the significance values of the independent variables except for personal adequacy, which implied that loyalty had more predictive power than personal adequacy. The Table 9 shows the final model summary with the changes, based on results of simultaneous regression which was used to determine the path estimates of the model.

The model (Figure 6) is the improved alternate turnover intention model. It can be seen that the path between personal adequacy and commitment had been removed as it was found to be insignificant 


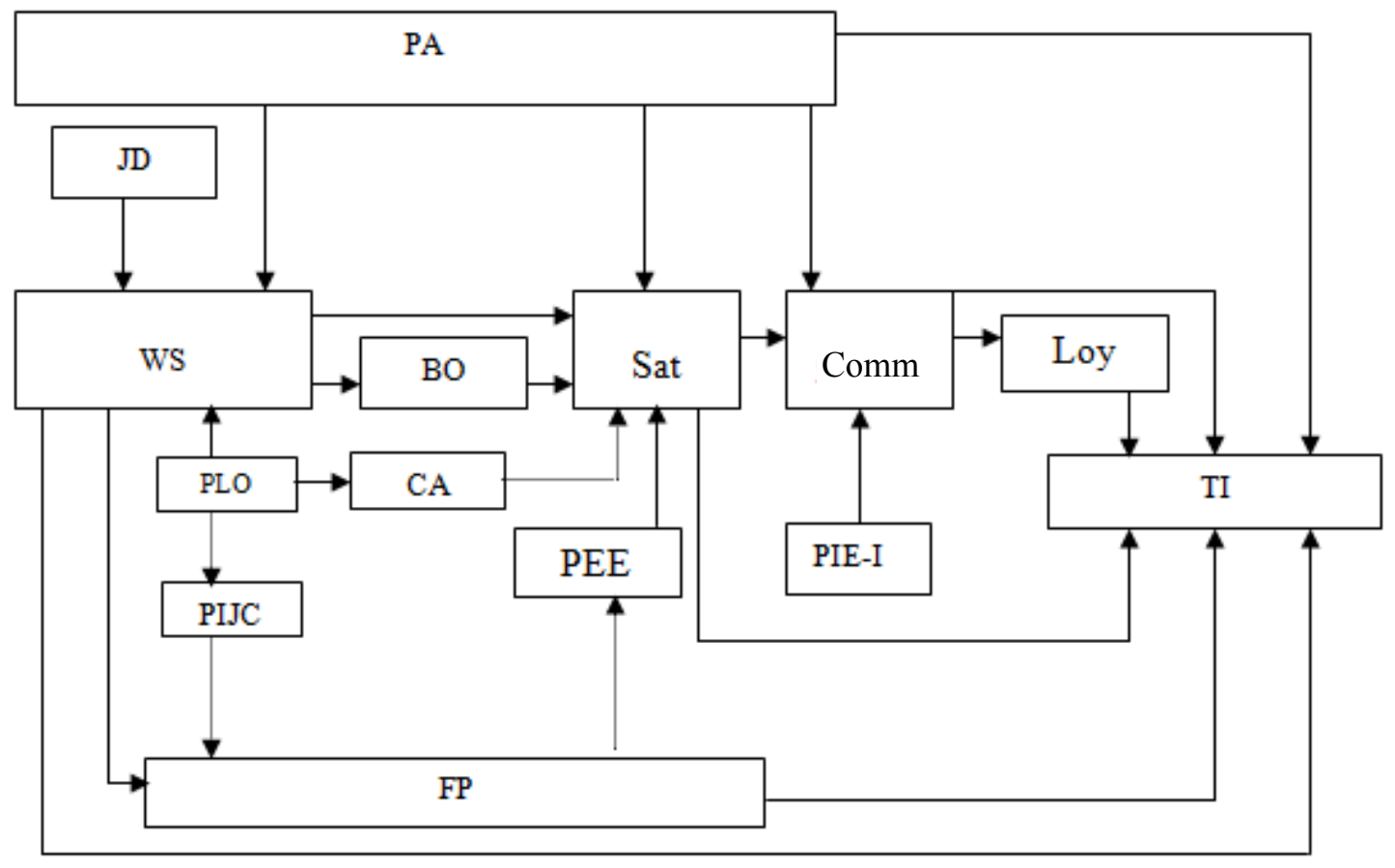

Note: Arrows with dotted lines are the newly added paths

Figure 4: Validated model with newly added paths.

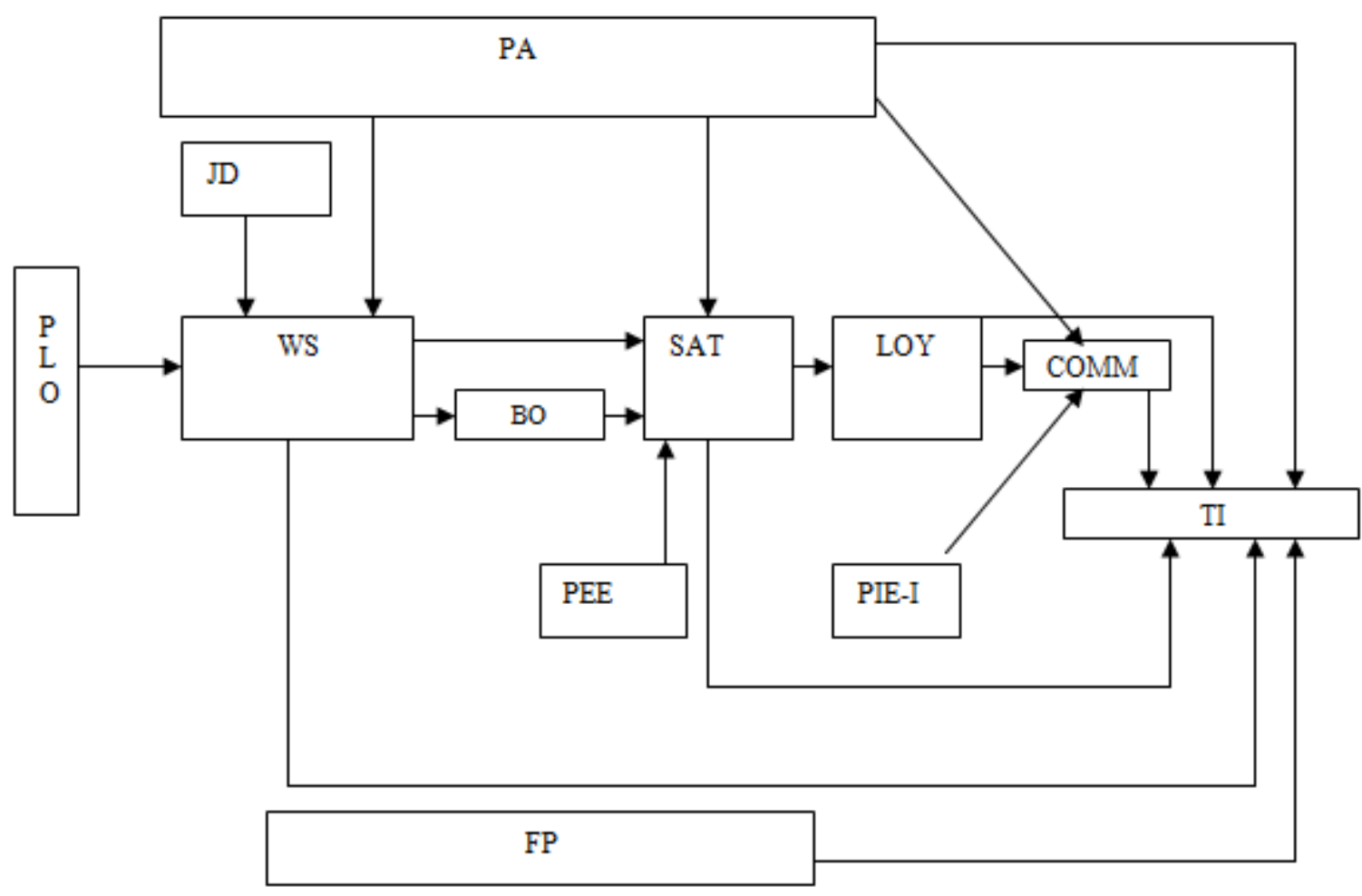

Figure 5: Proposed alternate model. 
Citation: Ravichandan K (2015) Application of Multiple Regressions in Development of an Employee Turnover Model. Int J Econ Manag Sci 4: 266. doi:10.4172/21626359.1000266

Page 12 of 18

\begin{tabular}{|c|c|c|c|c|c|c|}
\hline \multirow[t]{2}{*}{ Dependent Variable } & \multirow{2}{*}{$\begin{array}{l}\text { Independent } \\
\text { Variables }\end{array}$} & \multicolumn{2}{|c|}{ Un standardized coefficients } & \multirow{2}{*}{$\begin{array}{c}\text { Standardized } \\
\text { coefficients } \\
\text { Beta }\end{array}$} & \multirow[t]{2}{*}{ t-value } & \multirow[t]{2}{*}{ Adj. $R^{2}$} \\
\hline & & Beta & Std.error & & & \\
\hline \multirow[t]{7}{*}{ TI } & Constant & 4.796 & 0.255 & & $18.802^{* \star \star}$ & \multirow[t]{7}{*}{0.561} \\
\hline & PA & 0.149 & 0.039 & 0.131 & $3.851^{\star \star *}$ & \\
\hline & WS & 0.180 & 0.031 & 0.234 & $5.757^{* * *}$ & \\
\hline & FP & -0.138 & 0.042 & -0.123 & $-3.294^{* *}$ & \\
\hline & Loy & -0.266 & 0.037 & -0.298 & $-7.172^{\star \star \star}$ & \\
\hline & Comm & -0.193 & 0.042 & -0.181 & $-4.610^{\star \star *}$ & \\
\hline & Sat & -0.214 & 0.041 & -0.224 & $-5.156^{\star * \star}$ & \\
\hline \multirow[t]{2}{*}{ Loy } & Constant & 1.614 & 0.813 & & $8.802^{* * *}$ & \multirow[t]{2}{*}{0.238} \\
\hline & Comm & 0.586 & 0.052 & 0.490 & $11.337^{* * *}$ & \\
\hline \multirow[t]{4}{*}{ Comm } & Constant & 2.392 & 0.229 & & $10.448^{* * *}$ & \multirow[t]{4}{*}{0.241} \\
\hline & PA & 0.111 & 0.048 & 0.104 & $2.321^{*}$ & \\
\hline & PIE-I & -0.138 & 0.032 & -0.195 & $-4.366^{\star * *}$ & \\
\hline & Sat & 0.338 & 0.040 & 0.378 & $8.424^{* \star *}$ & \\
\hline \multirow{5}{*}{ Sat } & Constant & 4.084 & 0.237 & & $07.261^{* * *}$ & \multirow[t]{5}{*}{0.372} \\
\hline & PA & 0.131 & 0.048 & 0.110 & $2.723^{\star *}$ & \\
\hline & WS & -0.350 & 0.036 & -0.433 & $-9.608^{* \star *}$ & \\
\hline & BO & -0.191 & 0.045 & -0.189 & $-4.196^{\star * *}$ & \\
\hline & PEE & 0.099 & 0.033 & 0.122 & $3.040^{\star *}$ & \\
\hline \multirow[t]{2}{*}{ BO } & Constant & 1.726 & 0.097 & & $17.723^{\star * \star}$ & \multirow[t]{2}{*}{0.226} \\
\hline & WS & 0.382 & 0.035 & 0.476 & $10.905^{\star * *}$ & \\
\hline \multirow[t]{4}{*}{ WS } & Constant & 0.458 & 0.211 & & $2.173^{*}$ & \multirow[t]{4}{*}{0.594} \\
\hline & PA & -0.107 & 0.047 & -0.073 & $-2.258^{*}$ & \\
\hline & PLO & -0.139 & 0.042 & -0.105 & $-3.281^{* *}$ & \\
\hline & JD & 0.970 & 0.040 & 0.758 & $24.001^{* * *}$ & \\
\hline \multirow[t]{2}{*}{ PAEO } & Constant & 1.975 & 0.127 & & $15.526^{\star * *}$ & \multirow[t]{2}{*}{0.216} \\
\hline & PA & 0.0425 & 0.040 & 0.465 & $10.596^{\star * *}$ & \\
\hline \multirow[t]{2}{*}{ PLO } & Constant & 3.909 & 0.041 & & $33.585^{\star \star \star}$ & \multirow[t]{2}{*}{0.118} \\
\hline & $\mathrm{CA}$ & -0.304 & 0.041 & -0.344 & $-7.384^{\star \star \star}$ & \\
\hline
\end{tabular}

Table 4: Second-run regression table with significant predictors.

when loyalty as a measure of independent variable was introduced to determine commitment.

\section{Management Implications}

Losing good performing employees always had a negative impact on the firm. Employee retention is not only critical for cost efficiency but an important factor in revenue growth because of its link to customer acquisition and retention. There is a clear need for an organization to increase the level of commitment, satisfaction, and loyalty in order to decrease turnover intention of employees. This study demonstrated the effectiveness of model in predicting the turnover intention and its predictors. Management must understand the need for such a model. This study stressed the importance of 'job challenge, 'work autonomy', 'organization prospect', and 'supervisor-subordinate relationship' as important factors in determining loyalty, commitment and turnover intention. Lawler argued that a firm's human resource strategy should be centered on developing skills and ensuring motivation and commitment. The main role of software professional in an organization is to apply information technologies to solve business problems; they must master technical skills and also possess adequate knowledge of organization and business processes. As these professionals have less structured job roles, are required to have inter-disciplinary knowledge and skills and work in a cross functional team, effective leadership becomes important. The organization thus should stress the importance of effective leadership.

Organizational success in obtaining goals and objectives depends on managers and their leadership style. By using appropriate leadership styles, managers can influence employee job satisfaction, commitment and production. There exists no appropriate leadership style to follow. It all depends on the managers' ability to influence his/her subordinate to perform at the highest level. This depends on the extent to which the management respects workers, operates with honesty and establishes a high standard of integrity and has open lines of communication with the employees. Thus, the preference of leadership style depends on the type of culture that prevails in that organization. If an organization has open and free culture with much less rigid system and less level of bureaucracy, a free-rein leadership style can be preferred. But at the same time the leadership style also depends on the individual level An individual with low sense of personal adequacy might expect a more 'teaching type' leader than a free rein. A systematic and regular assessment of individual-need status should be carried out for adopting the preferred leadership style. As the software employees nature of job has become complex because of the targets and deadlines fixed, there is a tremendous increase in the job demands which induce stress. Stress has a direct influence on turnover intention and satisfaction. 
Citation: Ravichandan K (2015) Application of Multiple Regressions in Development of an Employee Turnover Model. Int J Econ Manag Sci 4: 266. doi:10.4172/21626359.1000266

Page 13 of 18

\begin{tabular}{|c|c|c|c|}
\hline Hypotheses & & & Results \\
\hline H1: The employees' sense of Personal Adequacy is negatively correlated with job stress. & PA & WS (-ve) & Supported \\
\hline $\begin{array}{l}\text { H2: The employees' sense of Personal Adequacy is positively correlated with the individuals' turnover } \\
\text { intention. }\end{array}$ & PA & $\mathrm{Tl}(+\mathrm{ve})$ & Supported \\
\hline H3: The employees' perceived learning opportunity is negatively correlated with job stress. & PLO & WS (-ve) & Supported \\
\hline $\mathrm{H}_{4}$ : The employees' perceived learning opportunity is negatively correlated with their level of career anxiety. & PLO & CA (-ve) & Supported \\
\hline $\mathrm{H}_{5}:$ The employees' career anxiety is positively correlated with their level of job stress. & $\mathrm{CA}$ & JS (+ve) & Not Supported \\
\hline $\begin{array}{l}\mathrm{H}_{6}: \text { The employees' sense of personal adequacy is positively correlated with their perceived alternate } \\
\text { employment opportunities. }\end{array}$ & PA & PAEO (+ve) & Supported \\
\hline $\begin{array}{l}\mathrm{H}_{7}: \text { The employees' perceived alternate employment opportunities are positively correlated with their } \\
\text { turnover intention. }\end{array}$ & PAEO & $\mathrm{Tl}(+\mathrm{ve})$ & Not Supported \\
\hline $\begin{array}{l}\mathrm{H}_{8}: \text { The employees' perceived intrinsic job characteristics are positively correlated with their level of } \\
\text { commitment. }\end{array}$ & PIJC & Com $(+v e)$ & Not Supported \\
\hline $\mathrm{H}_{9}$ : The employees' sense of personal adequacy is negatively correlated with their sense of job demands. & PA & JD (-ve) & Not Supported \\
\hline $\begin{array}{l}\mathrm{H}_{10}: \text { The employees' perception on their job demand is positively correlated with their perceived level of } \\
\text { stress. }\end{array}$ & JD & WS (+ve) & Supported \\
\hline $\mathrm{H}_{11}:$ The employees' sense of perceived job stress is negatively correlated with their level of job satisfaction. & WS & Sat (-ve) & Supported \\
\hline $\mathrm{H}_{12}:$ The employees' level of perceived job stress is positively correlated with their level of turnover intention. & WS & TI (+ve) & Supported \\
\hline $\mathrm{H}_{13}:$ The employees' sense of perceived job stress is positively correlated to with their level of job burnout. & WS & JB (+ve) & Supported \\
\hline $\mathrm{H}_{14}:$ The employees' level of burnout is negatively correlated with their sense of job satisfaction. & $\mathrm{BO}$ & Sat (-ve) & Supported \\
\hline $\mathrm{H}_{15}:$ The employees' perceived learning opportunity is positively correlated with their fit perceptions. & PLO & $\mathrm{FP}(+\mathrm{ve})$ & Not Supported \\
\hline $\mathrm{H}_{16}:$ The employees' perceived fit perceptions are positively correlated with their turnover intention. & FP & $\mathrm{TI}(-\mathrm{ve})$ & Supported \\
\hline $\begin{array}{l}\mathrm{H}_{17} \text { : Employees' pre-employment expectation is positively correlated with their level of satisfaction and } \\
\text { negatively related with their level of turnover intention. }\end{array}$ & PEE & $\begin{array}{l}\text { Sat }(+v e) \\
\text { TI (-ve) }\end{array}$ & $\begin{array}{l}\text { Supported } \\
\text { Not Supported }\end{array}$ \\
\hline $\begin{array}{l}\mathrm{H}_{1}: \text { The employees' internal perceived inequity is negatively related with their commitment and negatively } \\
\text { related with their turnover intention. }\end{array}$ & PEE-I & $\begin{array}{l}\text { Com }(-v e) \\
\text { TI (+ve) }\end{array}$ & $\begin{array}{l}\text { Supported } \\
\text { Not Supported }\end{array}$ \\
\hline $\begin{array}{l}\mathrm{H}_{1}: \text { The employees' external perceived inequity is negatively related with their commitment and negatively } \\
\text { related with their turnover intention. }\end{array}$ & PEE-E & $\begin{array}{l}\text { Com (-ve) } \\
\text { TI (+ve) }\end{array}$ & $\begin{array}{l}\text { Not Supported } \\
\text { Not Supported }\end{array}$ \\
\hline $\begin{array}{l}\mathrm{H}_{20}: \text { The employees' sense of personal adequacy is positively correlated with their level of organisational } \\
\text { commitment. }\end{array}$ & PA & Com (+ve) & Supported \\
\hline $\mathrm{H}_{21}:$ The employees' level of commitment is negatively correlated with their turnover intention. & Com & TI (-ve) & Supported \\
\hline $\begin{array}{l}\mathrm{H}_{22}: \text { The employees' sense of job satisfaction is positively correlated with their level of organisational } \\
\text { commitment }\end{array}$ & Sat & Com (+ve) & Supported \\
\hline $\begin{array}{l}\mathrm{H}_{23} \text { : The employees' sense of organisational commitment is positively correlated with their level of } \\
\text { organisational loyalty. }\end{array}$ & Com & Loy $(+v e)$ & Supported \\
\hline $\mathrm{H}_{24}:$ The employees' sense of organisational loyalty is negatively correlated with their turnover intention. & Loy & $\mathrm{TI}(-\mathrm{ve})$ & Supported \\
\hline $\mathrm{H}_{25}$ : The employees' sense of personal adequacy is positively correlated with their level of job satisfaction. & PA & Sat $(+\mathrm{ve})$ & Supported \\
\hline $\mathrm{H}_{26}:$ The employees' sense of job satisfaction is negatively correlated with their turnover intention. & Sat & TI (-ve) & Supported \\
\hline
\end{tabular}

Table 5: Results of the test of hypotheses.

The organization should try to reduce the induced level of stress. The software employees are thus becoming more workaholic and work in boundary-less time limit. The stress levels of new recruits are higher when compared to experience workers in a particular organization and the level of stress also increases if there exists a person-environment misfit. Stress management does not involve the total elimination of stressors; rather it is a reduction of stress to levels commensurate with tolerance and needs of individuals. Organization should give more importance to reduce the level of organizational stressors related to the job. Attaching importance to the organizational socialization process, education on human relations, social support system, and better communication system can lead to effective measures. It is important for the organizations to develop programmes for the early identification of stress, strain and the related health problems. For example, if this diagnosis reveals that time pressure, role in clarity and perceived learning opportunity are the stressors then these stressors can be reduced by job rotation and job enlargement which would increase the fit of an individual. When the organizations are able to reduce the stress level, they can have a work group with less fatigue, more commitment and high loyalty. The major problem that any organization faces in developing the retention strategies concerns payment. Almost all employees who quit voluntarily indicate less pay as the cause for their withdrawal. Even if at one end it can be considered as a socially desirable reason, on the other end this 'payment' as a reason should be seriously considered. As a number of software organizations are started in the country, job hopping and job hunting has increased tremendously. The qualified individuals are in great demand. The labor market is growing to a position where the demand will exceed the supply. The qualified employees thus enjoy an advantageous position to dictate their terms. Organizations are ready to pay as per the demands of the individual. Often an individual quits on payment dissatisfaction, and he opts for higher payment. Organizations should concentrate on this particular phenomenon and pay the employees by benchmarking the industry standards. The IT employees tend to bring with them strong individual skills and personal characteristics. As the organization recognizes and approves those skills and personal characteristics, IT employees should perceive greater fit with the organization's values and norms and they 


\begin{tabular}{|c|c|c|c|c|c|}
\hline \multirow[t]{2}{*}{ Independent Variable } & \multicolumn{2}{|c|}{ Un standardised coefficient } & \multirow{2}{*}{$\begin{array}{c}\begin{array}{c}\text { Standardised } \\
\text { coefficient }\end{array} \\
\text { Beta }\end{array}$} & \multirow{2}{*}{ t value } & \multirow[t]{2}{*}{ Sig } \\
\hline & Beta & Std.error & & & \\
\hline Personal adequacy & 0.06 & 0.044 & 0.56 & 1.354 & 0.176 \\
\hline Perceived inequity-internal & -0.176 & 0.029 & -0.248 & -5.969 & $0.000^{* * *}$ \\
\hline \multicolumn{6}{|l|}{ Satisfaction } \\
\hline Loyalty & 0.177 & 0.041 & 0.198 & 4.28 & $0.000^{* * *}$ \\
\hline \multirow[t]{2}{*}{ (Constant) } & 0.328 & 0.038 & 0.393 & 8.635 & $0.000^{* * *}$ \\
\hline & 2.018 & 0.215 & & 9.385 & 0 \\
\hline \multicolumn{6}{|c|}{ ANOVA: $F=57.917 \mathrm{df}(4,404)$ Significance value $=0.000$} \\
\hline \multicolumn{6}{|c|}{$R=0.604 \quad R$ square $=0.364$ Adjusted $R$ square $=0.358$} \\
\hline Dependent Variable: Commitment & & & & & \\
\hline
\end{tabular}

Table 6: Simultaneous regression table for commitment.

\begin{tabular}{|c|c|c|c|c|c|c|}
\hline \multirow{3}{*}{ Independent Variables } & \multirow{2}{*}{\multicolumn{2}{|c|}{$\begin{array}{c}\text { Standardised coefficients } \\
\text { Beta }\end{array}$}} & \multirow{2}{*}{\multicolumn{2}{|c|}{ t value }} & \multirow{2}{*}{\multicolumn{2}{|c|}{ Significance }} \\
\hline & & & & & & \\
\hline & Final & Alt & Final & Alt & Final & Alt \\
\hline $\begin{array}{l}\text { PA } \\
\text { PIE-I } \\
\text { Sat } \\
\text { Loy* }^{*}\end{array}$ & $\begin{array}{r}0.104 \\
-0.195 \\
0.378\end{array}$ & $\begin{array}{l}0.056 \\
-0.248 \\
0.198 \\
0.393\end{array}$ & $\begin{array}{l}2.321 \\
-4.366 \\
8.424\end{array}$ & $\begin{array}{l}1.354 \\
-5.969 \\
4.287 \\
8.653\end{array}$ & $\begin{array}{l}0.021 \\
0.000 \\
0.000\end{array}$ & $\begin{array}{l}0.176 \\
0.000 \\
0.000 \\
0.000\end{array}$ \\
\hline
\end{tabular}

Dependent variable: Commitment

* Added independent variable in the alternate model.

Table 7: Comparison of regression measures of commitment.

\begin{tabular}{|l|c|c|}
\hline Measures & Final & Alternate \\
\hline Constant: & 2.392 & 2.018 \\
Beta & 0.229 & 0.215 \\
Std.Error & 10.448 & 0.385 \\
t- value & 0.000 & 0.000 \\
Significance & 0.497 & \\
\hline Model Summary: & 0.247 & 0.604 \\
R & 0.241 & \\
$R^{2}$ & & \\
Adjusted $\mathrm{R}^{2}$ & & \\
\hline
\end{tabular}

Table 8: The Comparative measures of final and alternate model.

would tend to experience less role stress, high job satisfaction, and higher organizational commitment and will be less likely to leave the organization.

\section{Suggestions for Further Research}

According to the results, the data fit the model adequately. However, there were several paths that were not significant. It is suggested that the future researchers should explore alternative models to investigate whether a modified model would better explain the turnover intention.

A longitudinal study that includes the actual quitting should be investigated for further improvement in the explanation of the model on turnover intention. Based on the zero order correlation, relationships were found between career anxiety and satisfaction; fit perception and perceived intrinsic job characteristics, personal adequacy and preemployment expectations. It would be interesting to investigate these relationships further for enhancing the fit of the model.

\section{Conclusion}

Based on the preceding discussion of results, a few conclusions could be drawn from this study. It is hoped that this study has achieved one of its primary goals in developing a turnover intention model for software employees based on their opinions on work and non-workrelated factors. The study's second aim was to increase the predictive power of the final model.
The Researchers had assessed, to the extent possible, the direct and indirect effects of various factors influencing the turnover intention. The single most factors that had the highest influencing power on the turnover intention were found to be loyalty in both the final and the alternate model of turnover intention. Further examinations on the influences of specific aspects of job satisfaction on turnover intention revealed 'challenging job' had more influencing power than the other satisfaction dimensions. Further the study also revealed the major dimensions of satisfaction and their influence on commitment and loyalty. Given this, it can be concluded that organizations, which try to increase the employees' level of commitment and loyalty, can build strategies on the specific dimensions of satisfaction that influence loyalty and commitment. The study has tried to track the antecedents of turnover intention. The study has presented critical implications to the management and provided them with researchbased knowledge on the turnover intention of the employees in the organizational development field. Prior to this study only a few studies were conducted in the field of information technology and especially among the software professionals. Many models on turnover intention and many pieces of research on turnover intention exist but in a different organizational set up and different industries. This study on the development of employee turnover intention mode, could serve as a catalyst for future researchers for a better understanding of the employee-quitting behaviour. 
Citation: Ravichandan K (2015) Application of Multiple Regressions in Development of an Employee Turnover Model. Int J Econ Manag Sci 4: 266. doi:10.4172/21626359.1000266

\begin{tabular}{|c|c|c|c|c|c|c|c|}
\hline \multirow{2}{*}{$\begin{array}{l}\text { Dependent } \\
\text { Variable }\end{array}$} & \multirow{2}{*}{$\begin{array}{l}\text { Independent } \\
\text { Variables }\end{array}$} & \multicolumn{2}{|c|}{$\begin{array}{l}\text { Unstd. } \\
\text { Coeff. }\end{array}$} & \multirow{2}{*}{\begin{tabular}{|l|}
$\begin{array}{l}\text { Std. } \\
\text { coeff }\end{array}$ \\
Beta \\
\end{tabular}} & \multirow[t]{2}{*}{ t-value } & \multirow[t]{2}{*}{ Adj. $R^{2}$} & \multirow[t]{2}{*}{ Position } \\
\hline & & Beta & S.E & & & & \\
\hline \multirow{7}{*}{$\mathrm{TI}$} & Constant & 4.796 & 0.255 & & $18.802^{\star \star *}$ & \multirow{7}{*}{0.561} & \multirow{7}{*}{ Unchanged } \\
\hline & PA & 0.149 & 0.039 & 0.131 & $3.851^{* * *}$ & & \\
\hline & WS & 0.180 & 0.031 & 0.234 & $5.757^{\star \star *}$ & & \\
\hline & FP & -0.138 & 0.042 & -0.123 & $-3.294^{* *}$ & & \\
\hline & Loy & -0.266 & 0.037 & -0.298 & $-7.172^{\star \star \star}$ & & \\
\hline & Comm & -0.193 & 0.042 & -0.181 & $-4.610^{\star \star \star}$ & & \\
\hline & Sat & -0.214 & 0.041 & -0.224 & $-5.156^{\star \star \star}$ & & \\
\hline \multirow{2}{*}{ Loy } & Constant & 1.614 & 0.813 & & $8.802^{* \star \star}$ & \multirow{2}{*}{0.238} & \multirow{2}{*}{ Unchanged } \\
\hline & Comm & 0.586 & 0.052 & 0.490 & $11.337^{\star * *}$ & & \\
\hline \multirow{4}{*}{ Comm } & Constant & 2.392 & 0.229 & & $10.448^{* \star *}$ & \multirow{4}{*}{0.241} & \multirow{4}{*}{ Changed } \\
\hline & PA & 0.111 & 0.048 & 0.104 & $2.321^{*}$ & & \\
\hline & PIE-I & -0.138 & 0.032 & -0.195 & $-4.366^{\star \star *}$ & & \\
\hline & Sat & 0.338 & 0.040 & 0.378 & $8.424^{* * *}$ & & \\
\hline \multirow{5}{*}{ Sat } & Constant & 4.084 & 0.237 & & $07.261^{* \star *}$ & \multirow{5}{*}{0.372} & \multirow{5}{*}{ Unchanged } \\
\hline & PA & 0.131 & 0.048 & 0.110 & $2.723^{\star *}$ & & \\
\hline & WS & -0.350 & 0.036 & -0.433 & $-9.608^{* * *}$ & & \\
\hline & BO & -0.191 & 0.045 & -0.189 & $-4.196^{\star * \star}$ & & \\
\hline & PEE & 0.099 & 0.033 & 0.122 & $3.040^{* *}$ & & \\
\hline \multirow{2}{*}{ BO } & Constant & 1.726 & 0.097 & & $17.723^{\star \star \star}$ & \multirow{2}{*}{0.226} & \multirow{2}{*}{ Unchanged } \\
\hline & WS & 0.382 & 0.035 & 0.476 & $10.905^{\star * *}$ & & \\
\hline \multirow{4}{*}{ WS } & Constant & 0.458 & 0.211 & & $2.173^{*}$ & \multirow{4}{*}{0.594} & \multirow{4}{*}{ Unchanged } \\
\hline & PA & -0.107 & 0.047 & -0.073 & $-2.258^{*}$ & & \\
\hline & PLO & -0.139 & 0.042 & -0.105 & $-3.281^{\star *}$ & & \\
\hline & JD & 0.970 & 0.040 & 0.758 & $24.001^{* * *}$ & & \\
\hline \multirow{2}{*}{ PAEO } & Constant & 1.975 & 0.127 & & $15.526^{* * *}$ & \multirow{2}{*}{0.216} & \multirow{2}{*}{ Unchanged } \\
\hline & PA & 0.0425 & 0.040 & 0.465 & $10.596^{\star * *}$ & & \\
\hline \multirow{2}{*}{ PLO } & Constant & 3.909 & 0.041 & & $33.585^{\star * *}$ & \multirow{2}{*}{0.118} & \\
\hline & CA & -0.304 & 0.041 & -0.344 & $-7.384^{\star * *}$ & & Unchanged \\
\hline
\end{tabular}

${ }^{* * *} p<0.001,{ }^{* *} p<0.001,{ }^{*} p<0.05$

Table 9: Summary of measures of the alternate model.

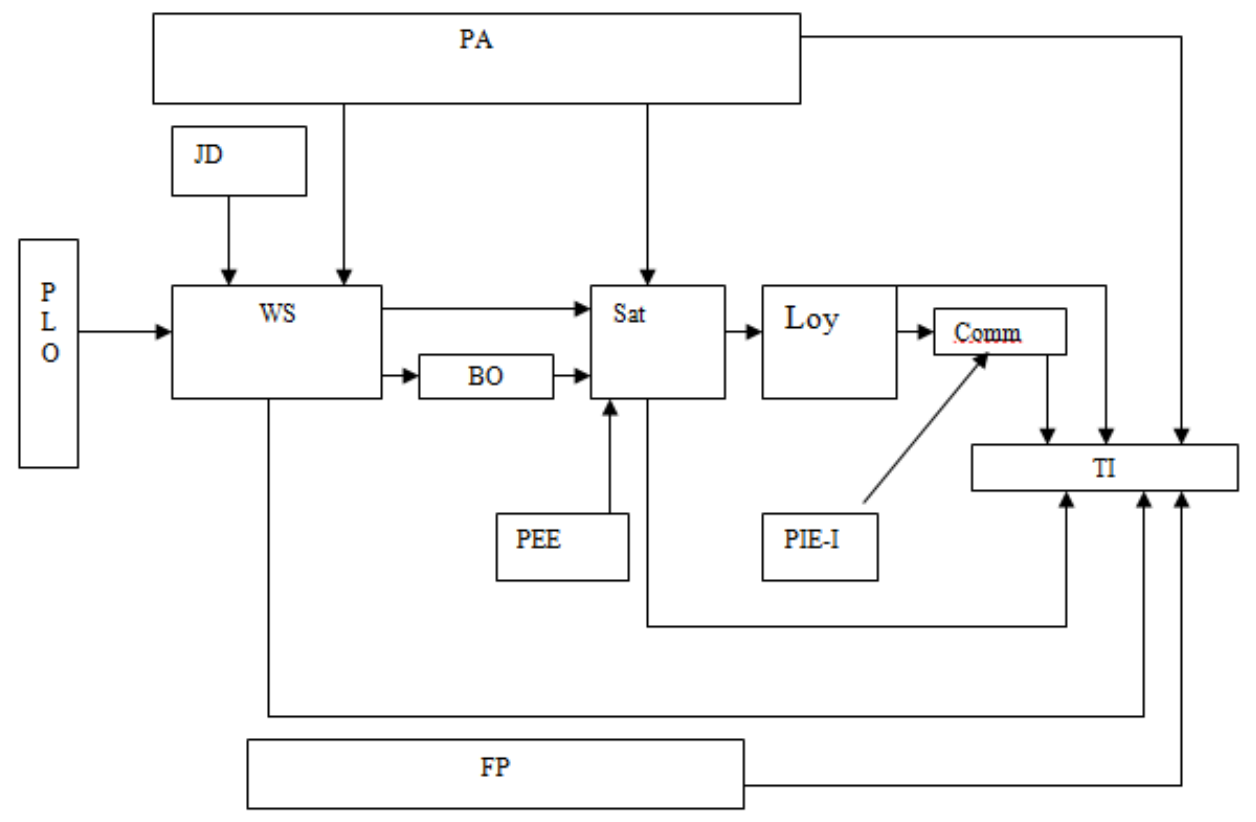

Figure 6: Validated alternate model. 
Citation: Ravichandan K (2015) Application of Multiple Regressions in Development of an Employee Turnover Model. Int J Econ Manag Sci 4: 266. doi:10.4172/21626359.1000266

Page 16 of 18

\section{References}

1. Kazmierczack MF, Josh J, Archey WT (2011) Losing the competitive advantage? The Challenge for Science and Technology in the United States.

2. Gary H, Prahalad CK (1990) The Core Competence of the Corporation. Harvard Business Review 68: 79-93.

3. Bryan LL, Joyce Cl, Weiss LM (2006) Making a Market in Talent.

4. Carnicer MP, Sanchez AM, Perez MP, Limenez MJV (2004) Analysis of Interna and External Labor Mobility: A Model of Job-related and Non-related factors. Personnel Review 33: 222-240.

5. Kacmar KM, Bozeman DP, Carlson DS, Anthony WP (1999) An Examination of the Perceptions of Organizational Politics Model: Replication and Extension. Human Relations 52: 383-416.

6. McEvoy GM, Cascio WF (1985) Strategies for reducing employee turnover: A Meta-analysis. Journal of Applied Psychology 70: 342-353.

7. Barak MEM, Nissly JA, Levin A (2001) Antecedents to Retention and Turnover among Child Welfare, Social Work, and other Human Service Employees: What can We Learn from Past Research? A Review and Meta-analysis. Social Service Review 75: 625-661.

8. Powell MJ, York RO (1992) Turnover in Country Public Welfare Agencies. Journal of Applied Social Sciences 16: 111-127.

9. Lin S, Chang J (2005b) Goal Orientation and Organizational Commitment as Explanatory Factors of Employees' Mobility. Personnel Review 34: 331-353.

10. Taylor S (2005) The Employee Retention Handbook, Jaico Publishing House, Noida: $44-45$.

11. Balfour DL, Neff DM (1993) Predicting and Managing Turnover in Human Service Agencies: A Case Study of an Organization in Crisis. Public Personnel Management 22: 473-486.

12. Philliphs D (1990) The Price Tag on Turnover. Personnel Journal: 58-61.

13. Schlesinger LA, Heskett JL (1991) Breaking the Cycle of Failures in Services. Sloan Management Review: 32: 17-28.

14. Agarwal NM (2000) Human Issues and Challenges in Indian Software Industry. Working Paper, April, Indian Institute of Management, Bangalore, India.

15. Ajzen I (1991) The Theory of Planned Behaviour. Organizational Behavior and Human Decision Processes 50: 179-211.

16. Newman JE (1974) Predicting absenteeism and turnover: a field comparison of Fishbein's model and traditional job attitude measures. Journal of Applied Psychology 59: 610-6155.

17. Mobley WH, Horner SO, Hollingsworth AT (1978) An evaluation of precursors of hospital employee turnover. Journal of Applied Psychology 63: 408-414

18. Mitchell TR, Holtom BC, Lee TW, Sablynski C, Erez M (2001) Why People Stay: Using Job Embeddedness to Predict Voluntary Turnover. Academy of Management Journal 44: 1102-1121.

19. Mobley WH, Griffith RW, Hand HH, Meglino BM (1979) Review and conceptual analysis of the employee turnover process. Psychological Bulletin 36: 493-521.

20. Porter LW, Steers RM (1973) Organizational work, and Personal factors in Employee Turnover and Absenteeism. Psychological Bulletin 80: 151-176.

21. Rhodes SR, Doering M (1983) An Integrated Model of Career Change, Academy of Management Review 8: 631-639.

22. Cotton JL, Tuttle JM (1986) Employee turnover: a meta-analysis and review with implications for research. Academy of Management Review 11: 55-70.

23. Rosenberg M (1965) Society and Adolescent self-image, Princeton, NJ: Princeton University press.

24. Silverstone PH (1991) Low self-esteem in psychiatric conditions. British Journal of Clinical Psychology 30: 185-188.

25. Waters LE, Moore KA (2002) Self-esteem and coping: a comparison of unemployed and re-employed people. Journal of Organizational Behaviour 23: $1-12$

26. Lucy F, Mellor DJ, Moore KA, Claude L (2004) How can Managers Reduce Employee Intention to Quit? Journal of Managerial Psychology 19: 170-187.
27. Greenhaus J, Badin IJ (1974) Self-esteem, performance, and satisfaction: some tests of a theory. Journal of Applied Psychology 59: 722-726.

28. Inkson KJH (1978) Self-esteem as a moderator of the relationship between job performance and job satisfaction. Journal of Applied Psychology 63: 243-247.

29. Kohli AA (1985) Some unexplored supervisory behaviors and their influences on salespeople's role clarity, specific self-esteem, job satisfaction, and motivation. Journal of Marketing Research 22: 424-433.

30. Tang TL, Reynolds DB (1993) Effects of self-esteem and perceived goal difficulty on goal setting, certainty, task performance, and attributions. Human resource Development Quarterly 4: 153-170.

31. Tang TL, Gilbert PR (1994) Organizations-based self-esteem among mental health workers: A replication and extension. Public Personnel Management 23: 127-134.

32. Mone MA (1994) Relationships between Self-concepts, Aspirations, Emotional Responses and Intent to Leave a Downsizing Organization. Human Resource Management 33: 281-298.

33. Rogers EM (1983) Diffusion of Innovations (3rdedn) Free press, New York, USA

34. Moore JE (2000) One Road to Turnover: An Examination of Work Exhaustion in Technology Professionals. MIS Quarterly 24: 141-168.

35. Brief AP, Aldag RJ (1980) Antecedents of organizational commitment among hospital nurses. Sociology of Work and Occupations 7: 210-221

36. Jex SM, Bliese PD (1999) Efficacy Beliefs as a Moderator of the Impact of Work-related Stressors: A Multilevel Study. Journal of Applied Psychology 84: 349-361.

37. Grau R, Salanova M, Peiro JM (2001) Moderator Effects of Self-efficacy on Occupational Stress. Psychology in Spain 5: 63-74.

38. Chao GT, O'leary-Kelly AM, Samantha W, Klein HJ, Gardner PD (1994) Organisational Socialisation: Its content and Consequences. Journal of Applied Psychology 79: 730-743.

39. Schneider B (1987) The people make the place, Personnel Psychology 40: $437-453$

40. Wanous JP, Stumpf SA, Bedrosian H (1979) Job Survival of New Employees Personnel Psychology 32: 651-662.

41. Porter G, Tansky (1999) Expatriate Success may depend on a Learning Orientation: Considerations for Selection and Training. Human Resource Management 38: 46-60

42. Porter L, Crampon W, Smith F (1976) Organizational commitment and managerial turnover: a longitudinal study. Organizational Behaviour and Human Performance 15: 87-98.

43. McHugh M (1997) Stress at Work: Do Managers really Count the Costs Employee Relations 15: 18-32.

44. Ashford SJ, Lee C, Bobko P (1989) Content, causes and consequences of job insecurity: a theory-based measure and substantive test. Academy of Management Journal 32: 803-829.

45. Hallier J, Lyon P (1996) Job Insecurity and Employee Commitment: Managers Reactions to the Threat and Outcomes of Redundancy Selection. British Journal of Management 17: 107-123.

46. Chawla A, Kelloway EK (2004) Predicting Openness and Commitment to Change. The Leadership and Organization Development Journal 25: 485-498.

47. Reilly A, Brett J, Stroh L (1993) The Impact of Corporate Turbulence on Managers' Attitudes. Strategic Management Journal 14: 167-179.

48. Roskeis E, Louis-Guerin C (1990) Job Insecurity in Managers: Antecedents and Consequences. Journal of Organizational Behavior 11: 345-359.

49. Farris GF (1971) A predictive study of Turnover. Personnel Psychology 24: $311-325$

50. Hom PW, Caranikas-Walker F, Prussia GE, Griffeth RW (1992)A Meta-analytica Structural Equations Analysis of a Model of Employee Turnover. Journal of Applied Psychology 78: 890-909.

51. Sager JK, Varadharajan PR, Futrell CM (1988) Understanding salesperson turnover: a partial evaluation of Mobley's turnover process model. Journal of Personal Selling and Sales Management 8: 20-35. 
Citation: Ravichandan K (2015) Application of Multiple Regressions in Development of an Employee Turnover Model. Int J Econ Manag Sci 4: 266. doi:10.4172/21626359.1000266

52. Michaels CE, Spector PE (1982) Causes of Employee Turnover: a test of Mobley, Griffeth, Hand, and Meglino model of employee turnover. JAP 67: 53-79.

53. Steel RP, Griffeth RW (1989) The Elusive Relationship between Perceived Employment Opportunity and Turnover Behaviour: A Methodological or Conceptual Artifact? Journal of Applied Psychology 74: 846-854.

54. Hulin CL, Roznowski M, Hachiya D (1985) Alternative opportunities and withdrawal decisions: Empirical and theoretical discrepancies and an integration. Journal of Applied Psychology 97: 233-250.

55. Milliman J, Ferguson J, Trickett D, Condemi B (1999) Spirit and community at Southwest Airlines: an investigation of a spiritual values-based model. Journal of Organizational Change Management 12: 221-233.

56. Mano-Negrin R, Tzafrir SS (2004) Job search modes and turnover. Career Development International 9: 442-458.

57. Curry JP, Wakefield DS, Price JL, Mueller CW (1986) On the causal ordering of job satisfaction and organizational commitment. Academy of Management Journal 29: 847-858.

58. Bretz RD, Judge TA (1994) Person-organization Fit and the Theory of Work Adjustment: Implications for Satisfaction, Tenure and Career Success. Journal of Vocational Behaviour 44: 32-54.

59. Stevens JM, Beyer JM, Trice HM (1978) Assessing Personal, Role and Organizational Predictors of Managerial Commitment. Academy of Management Journal 21: 380-396.

60. Mowday RT, Spencer DG (1981) The influence of task and personality characteristics on employee turnover and absenteeism incidents. Academy of Management Journal 24: 634-642.

61. Morris JH, Steers RM (1980) Structural influences on organizational commitment. Journal of Vocational Behavior 15: 50-57.

62. Brown SP, Peterson RA (1994) The Effect of Effort on Sales Performance and Job Satisfaction. Journal of Marketing 58: 70-80.

63. Niehoff BP, Enz CA, Grover RA (1990) The Impact of Top Management Actions on Employee Attitudes and Perception. Group and Organization Studies 15: 337-352.

64. Westman M (1992) The Moderating Effects of Decision Latitude on Stress strain Relationships: Does Organizational Level Matter? Journal of Organizational Behavior 13: 713-722.

65. Eisenberger R, Fasolo P, Davis-La MV (1990) Perceived Organizational Support and Employee Diligence, Commitment, and Innovation. Journal of Applied Psychology 75: 51-59.

66. Fox ML, Dwyer DJ, Ganster DC (1993a) Effects of Stressful Job Demands and Control on Physiological and Attitudinal Outcomes in a Hospital Setting. Academy of Management Journal 36: 292.

67. Williams KJ, Alliger GM (1994) Role Stressors, Mood Spill over and Perceptions of Work Family Conflict in Employed Parents. Academy of Management Journal 37: 837-865.

68. Maslach C, Jackson SE (1984) Burnout in organizational settings in Oskamp, S (Ed.), Applied Social Psychology Annual: Applications in Organizational Settings 5, CA, pp. 133-53.

69. Kahn R (1978) Job burnout: prevention and remedies. Public Welfare 36: 61-63.

70. Pines A, Maslach C (1978) Characteristics of staff burnout in mental health settings. Hospital and Community Psychiatry 29: 233-237.

71. Fox ML, Dwyer DJ, Ganster DC (1993b) Effects of Stressful Job Demands and Control on Physiological and Attitudinal Outcomes in a Hospital Setting. Academy of Management Journal 36: 289-318.

72. Newman JE, Beehr TA (1979) Personal and Organizational Strategies for Handling Job Stress: A Review of Research and Opinion. Personnel Psychology 32: 1-43.

73. Kahn RL, Byosiere P (1992) Stress in Organizations. In: Handbook of Industrial and Organizational Psychology, CA: Consulting Psychologists Press, Inc.

74. McGrath JE () Stress and behaviour in organizations, In: Handbook of industrial and organization psychology 1: 351-1395.

75. French JRP, Caplan RD (1973) Organizational stress and individual strain. In: the failure of success. DIEditor Morrow, A, J: 30-66.
76. Mikkelsen A, Ogaard T, Lovrich N (2000) Modeling the effects of organizationa setting and individual coping style on employees' subjective health, job satisfaction and commitment. Public Administration Quarterly 24: 371-397.

77. Fisher CD, Gitelson RG (1983) A meta-analysis of the correlates of role conflict and ambiguity. Journal of Applied Psychology 68: 320-333.

78. Laschinger HKS, Shamian J, Thomson D (2001) Impact of magnet hospital characteristics on nurses' perceptions of trust burnout quality of care, and work satisfaction. Nursing Economics 19: 209-219.

79. Matteson MT, Ivancevich JM (1987) Controlling work stress: San Francisco: Jossy-Bass Inc.

80. Bhanugopan R, Fish A (2006b) An Empirical Investigation of Job Burnout among Expatriates. Personnel Review 35: 450

81. Houkes IP, de Jonge J, Bakker AB (2003) Specific determinants of intrinsic work motivation, emotional exhaustion and turnover intention: a multisample longitudinal study. Journal of Occupational \& Organizational Psychology 76: 427.

82. Umiker W (1992) Motivating the burned out employee. Health care Supervisor 11: $21-26$.

83. Froiland $P$ (1993) What cures job stress? Taining 30: 32-36.

84. Jackson S, Schuler R (1985) A Meta-Analysis and Conceptual Critique of Research on Role Ambiguity and Role Conflict in Work Settings. Organisational Behaviour and Human Decision Processes 36: 16-78.

85. Dwyer DJ, Ganster DC (1991) The Effects of Job Demands and Control on Employee Attendance and Satisfaction. Journal of Organizational Behavior 12 595-608.

86. Erickson J, Pugh WM, Gunderson EKE (1972) Status Congruency as a Predictor of Job Satisfaction and Life Stress. Journal of Applied Psychology 56: 523-525.

87. Spector PE, Jex SM (1991) Relations of Job Characteristics from Multiple Data Sources with Employee Affect, Absence, Turnover Intentions, and health. Journal of Applied Psychology 76: 46-53

88. Kristof A (1996) Person-organisation Fit: An Integrative Review of its Conceptualization, Measurements and Implications. Personnel Psychology 49: 1-50.

89. Steffy BD, Shaw KN, Noe AW (1989) Antecedents and consequences of job search behaviors. Journal of Vocational Behaviour 35: 254-263.

90. Dreher GF, Bretz RD (1991) Cognitive ability and career attainment Moderating effects of early career success. Journal of Applied Psychology 76: 392-397.

91. Ahlburg D, Glomb T, Wanberg C, Kammeyer MJ, Chuang A (2003) U of $M$ Retention study. Final report/Newsletter, Industrial Relations Center, Carlson School of Management, University of Minnesota.

92. Rizzo JR, House RJ, Lirtzman SI (1970) Role conflict and ambiguity in complex organizations. Administrative Science Quarterly 15: 150-163.

93. Cascio WF (1991) Applied Psychology in Personnel Management, In: Foote DA (2004) Temporary workers: Managing the problem of unscheduled Turnover. Management Decision 42: 968.

94. O'Reilly C, Chatman J (1986) Organizational commitment and psychologica attachment: the effects of compliance, identification, and internalization on pro-social behavior. Journal of Applied Psychology 71: 492-499.

95. Mowday RT (1998) Reflections on the study and relevance of organizationa commitment. Human Resource Management Review 8: 387-402.

96. Mathieu JE, Zajac DM (1990) A review and meta-analysis of the antecedents correlates, and consequences of organizational commitment. Psychological Bulletin 108: 951-995.

97. Hom PW, Griffeth RW (1995) Employee Turnover, South/Western, Cincinnati, OH.

98. Williams LJ, Hazer JT (1986) Antecedents and consequences of satisfaction and commitment in turnover models: a reanalysis using latent variable structural equation methods. Journal of Applied Psychology 71: 19-31.

99. Chen XP, Hui C, Sego DJ (1998) The role of Organizational Citizenship Behavio in Turnover: Conceptualization and Preliminary Test of Key Hypothesis. JAP 83: $922-931$ 
Citation: Ravichandan K (2015) Application of Multiple Regressions in Development of an Employee Turnover Model. Int J Econ Manag Sci 4: 266. doi:10.4172/21626359.1000266

100. Putterill MS, Rohrer TC (1995) A Causal Model of Employee Commitment in a Manufacturing Setting. International Journal of Manpower 16: 65.

101.Scholl RW (1981) Differentiating Organizational Commitment from Expectancy as a Motivating Force. Academy of Management Review 6: 589-599.

102.Bateman TS, Strasser S (1984) A longitudinal analysis of the antecedents of organizational commitment. Academy of Management Journal 27: 95-112.

103. Marsh RM, Mannari H (1977) Organizational Commitment and Turnover: A Predictor Study. Administrative Science Quarterly 21: 57-75.

104. Brown SP, Peterson RA (1993) Antecedents and Consequences of Salesperson Job Satisfaction: Meta-analysis and Assessment of Causal Effects. Journal of Marketing Research 30: 63-77.

105. Igbaria M, Guimaraes T (1999) Exploring Differences in Employee Turnover Intentions and Its Determinants among Telecommuters and Non Telecommuters. Journal of MIS 16: 147-164.

106. Cramer D (1996) Job Satisfaction and Organizational Continuance Commitment: A Two-wave Panel Study. Journal of Organizational Behavior 17: 389-400.

107. Brooke PP, Russell DW, Price JL (1988) Discriminant Validity of Measures of Job Satisfaction, Job Involvement, and Organizational Commitment. Journal of Applied Psychology 73: 139-145.

108. Sibson S (2006) Rewards of Work Study.

109. Capelli P (2000) A market-driven approach to retaining talent. Harvard Business Review 78: 103-113.

110. Misener TR, Haddock KS, Gleaton JU, Ajamieh AR (1996) Toward an international measure of job satisfaction. Nursing Research 45: 87-91.

111. Irvine DM, Evans MG (1995) Job satisfaction and turnover among nurses: integrating research findings across studies. Nursing Research 44: 246-253.

112. Mosadegh Rad AM, Yarmohammadian MH (2006) A Study of Relationship between Managers' Leadership Style, and Employees' Job Satisfaction. Leadership in Health Services 19: 11-18.

113. Fern EF, Avila RA, Grewal D (1989) Sales force turnover: those who left and those who stayed. Industrial Marketing Management 18: 1-9.

114. Futrell CM, Parasuraman A (1984) The relationship of satisfaction and performance to sales force turnover. Journal of Marketing 48: 33-40.

115. Lin S, Chang J (2005b) Goal Orientation and Organizational Commitment as Explanatory Factors of Employees' Mobility. Personnel Review 34: 331-353.

116. Abraham R (1999) The Impact of Emotional Dissonance on Organizational Commitment and Intention to Turnover. The Journal of Psychology 133: 441-455.

117. Tuten TL, Niedermeyer PE (2004) Performance, Satisfaction and Turnove in Call Centers: The Effects of Stress and Optimism. Journal of Business Research 57: 26-34.

118. Rusbult CE, Farrell D (1983) A longitudinal test of the investment model the impact of job satisfaction, job commitment, and turnover on variations in rewards, costs, alternatives, and investments. Journal of Applied Psychology 68: 429-438.

119. Price JL, Mueller CW (1986) A causal model of turnover for nurses. Academy of Management Journal 24: 543-565.

120. Hom PW, Griffeth RW (1991) Structural equations modeling test of turnove theory: Cross-sectional and longitudinal analyses. Journal of Applied Psychology 76: 350-366

121. Crampton SM, Wagner JA (1994) Percept-percept inflation in microorganizational research: an investigation of prevalence and effect. Journal of Applied Psychology 79: 67-76.

122. Blau GJ (1987) Locus of control as a potential moderator of the turnover process. Journal of Occupational Psychology 60: 21-29.

123. Sager JK (1994) A structural model depicting salespeople's job stress. Journal of the Academy of Marketing Science 22: 74-84.
124. Mannheim B, Baruch Y, Tal J (1997) Alternative Models for Antecedents and Outcomes of Work Centrality and Job Satisfaction of High-tech Personnel. Human Relations 50: 1537-1561.

125. Williams ES, Konrad TR, Scheckler WE, Pathman D, Linzer M, et al. (2001) Understanding physicians' intentions to withdraw from practice: the role of job satisfaction, job stress, mental and physical health. Health Care Management Review 26: 7-19.

126. Porter LM, Mowday RT, Steers RM (1982) Employee-Organizational Linkage: the Psychology of Commitment, Absenteeism, and Turnover. American Journal of Sociology 88: 1315-1317.

127. Blau G (2000) Job, Organizational, Professional context Antecedents as Predictors of Intent for Inter role Work Transitions. Journal of Vocational Behavior 56: 330-445.

128. Vandenberg RJ, Nelson JB (1999) Disaggregating the motives underlying turnover intentions: when do intentions predict turnover behavior. Human Relations 52: 1313-1336.

129. Sheldon ME (1971) Investments and involvements as mechanisms producing commitment to the organization. Administrative Science Quarterly 16: 142-150.

130. Koch JL, Steers RM (1978) Job attachment, satisfaction and turnover among public employees. Journal of Vocational Behavior 12: 119-128.

131.Spencer DG, Steers RM (1980) The influence of personal factors and perceived work experiences on employee turnover and absenteeism. Academy of Management Journal 23: 567-572.

132. Morris JH, Sherman JD (1981) Generalizability of an organizational commitment model. Academy of Management Journal 24: 512-526.

133. Youngblood SA, Mobley WH, Meglino BM (1983) A longitudinal analysis of the turnover process. Journal of Applied Psychology 68: 507-516.

134. Hellman $\mathrm{CH}$ (1997) Job satisfaction and intent to leave. Journal of Social Psychology 137: 677-689.

135. Gregson T, Wendell J (1994) Role conflict, role ambiguity, job satisfaction and the moderating effects of job related self-esteem: A latent variable analysis. Journal of Applied Business Research 20: 106-113.

136. Arnold HJ, Feldman DC (1982) A Multivariate Analysis of the Determinants of Job Turnover. Journal of Applied Psychology 67: 350-360.

137. Saks AM, Ashforth BE (2002) Is job search related to employment quality? It all depends on the fit, JAP 87: 646-654.

138. Lee R, Ashforth B (1993) A longitudinal study about job burnout among supervisors and managers: comparisons between Leiter and Maslach (1988) and Golembiewshi et al. (1996) Organizational Behavior and Human Decision Processes 54: 369-398.

139. Cable DM, Judge TA (1996) Person-Organization fit, job choice decisions, and organizational entry. Organizational Behavior and Human Decision Processes 67: 294-311.

140. Kacmar KM, Bozeman DP, Carlson DS, Anthony WP (1999) An Examination of the Perceptions of Organizational Politics Model: Replication and Extension. Human Relations 52: 383-416. 